ISSN:1308-8173

Geliș Tarihi: 09.10.2021
E-ISSN: $1308-8505$

Kabul Tarihi: 04.11.2021
YIL: 2021

ÖZGÜN ARAŞTIRMA
Cilt: 36 Sayı: 4 Sayfa: $811-842$

Doi: 10.24988/ije.1007551

\title{
Türkiye'nin 2010 Sonrası Yönetim Bilişim Sistemleri Alanında Uluslararası Q1 Dergilerinde Durumu
}

\author{
Muhammet DAMAR ${ }^{1}$, Ömer AYDIN²*
}

Özet

Yönetim Bilişim Sistemleri (YBS) alanında çalışma yapan araştırmacılar, sürdürülebilir bir literatürün oluşmasında önemli bir rol oynayan bilimsel dergiler aracılığı ile alanı takip edebilmekte ve bilimsel çalıșmalarını yine bu dergiler aracılığı ile diğer bilim insanlarının ilgisine sunabilmektedir. Scimago Journal and Country Rank kaynaklarına göre, uluslararası düzeyde 2021 yılı itibariyle 104 dergi YBS alanında faaliyetlerini yürütmektedir. Çalışma, Türkiye özelinde, SCImago listesinde yer alan uluslararası YBS dergileri üzerinde genel bir değerlendirme sunmayı, uluslararası Q1 dergilerin diğer alanlar ile ilișkileri ve dergilerin nitelikleri hakkında genel bir değerlendirmeyi ve Q1 dergilerde 2010 yılından günümüze Türkiye adresli makalelerin bibliyometrik analizini gerçekleștirmektedir. Bu sayede uluslararası nitelikteki dergilerde Türkiye'deki YBS alanında çalışan araştırmacılarımızın bilimsel üretkenliği değerlendirilmektedir. Ayrıca YBS alanının Türkiye'de gelișimine katkı sunan kiși, kurum veya fikirlere yer vererek bu alana bir gelecek vizyonu sunma amacındadır. Türkiye'deki YBS disiplinin gelişmesinde, yurtdıșında halen çalışan veya bir dönem çalışmış araștırmacıların etkisinin büyük olduğu görülmüștür. İlgili araștırmacılar (Izak Benbasat, Dursun Delen, Tuğrul Daim, vb.) uluslararası YBS disiplinin gelişmesinde de önemli katkılar sunmuşlar ve akademide saygın bir konuma sahiptirler. Türkiye'deki uluslararası dergi faaliyetleri, yazılımda kalite, yazılım sektörünü geliştirmeye dönük literatür çalışmaları, YBS literatüründe iyileştirilmeye açık alan olarak karşımıza çıkmaktadır. Elde edilen tüm bulgular ışı̆̆ında Türkiye’deki YBS disiplinin daha nitelikli ve uluslararası normlarda gelișebilmesi için öneriler sunulmaktadır.

Anahtar kelimeler: Yönetim bilişim sistemleri, SCImago, bibliyometri, uluslararası ybs dergileri, q1 dergiler Jel Kodu: M15, M19, I23

\section{The Status of Turkey in International Q1 Journals in the Field of Management Information Systems After 2010}

\begin{abstract}
Researchers working in the field of Management Information Systems (MIS) follow the field through scientific journals that play an important role in the formation of sustainable literature. At the same time, these researchers can present their scientific studies to the attention of other scientists through these journals. According to the sources of Scimago Journal and Country Rank, as of 2021, 104 journals are publishing in the field of MIS at the international level. This study aims to provide a general evaluation of the international MIS journals in the SCImago list. In addition, this study carries out a general evaluation of the relations of international Q1 journals with other fields, the qualities of these journals, and bibliometric analysis of articles from Turkey in Q1 journals since 2010. In this way, the scientific productivity of researchers working in the field of MIS in Turkey is evaluated in international journals. In addition, it aims to present a future vision to this field by including people, institutions or ideas that contribute or will contribute to the development of MIS field in Turkey. It has been observed that researchers who are still working or have worked abroad have a great impact on the development of the MIS discipline in Turkey. Related researchers (Izak Benbasat, Dursun Delen, Tuğrul Daim, etc.) have also made important contributions to the development of the international MIS discipline and have a respected position in the academy. International journal activities in Turkey, quality in software, literature studies aimed at improving the software industry appear as areas open to improvement in the MIS literature. In the light of all the findings obtained, suggestions are presented for the MIS discipline in Turkey to develop more qualified and international norms.
\end{abstract}

Keywords: Management information systems, SCImago, bibliometrics, international mis journals, q1 journals Jel Codes: M15, M19, I23

ATIF ÖNERİsí (APA): Damar, M., Aydın, Ö. (2021). Türkiye'nin 2010 Sonrası Yönetim Bilişim Sistemleri Alanında Uluslararası Q1 Dergilerinde Durumu. İzmir Íktisat Dergisi, 36(4). 811-842. Doi: 10.24988/ije.1007551

${ }^{1}$ Dr. Öğr. Gör., Dokuz Eylül Üniversitesi, Bilgi İșlem Daire Bașkanlığı, İzmir, Türkiye

EMAIL: muhammet.damar@deu.edu.tr ORCID: 0000-0002-3985-3073

2, Dr. Öğr. Üyesi, Manisa Celal Bayar Üniversitesi, Mühendislik Fakültesi, Elektrik Elektronik Mühendisliği, Manisa, Türkiye EMAIL: omer.aydin@cbu.edu.tr ORCID: 0000-0002-7137-4881

* Sorumlu yazar (Corresponding author) 


\section{GíRiş}

YBS, yönetim bilişim sistemleri, birçok bilgi teknolojisi formunun toplumsal, kurumsal, grup ve bireysel düzeylerde stratejik, yönetsel ve operasyonel uygulamalarına odaklanan profesyonel ve uygulamalı bir disiplindir. Bilişsel psikoloji, bilgisayar bilimi, ekonomi, operasyon yönetimi, organizasyon felsefesi ve mühendislik kavramlarını içerir ve ilgili disiplinlerle etkileşim halindedir (Culnan, 1987; Baskerville ve Myers, 2002; Katerattanakul vd., 2006). Adeoti-Adekeye (1997)'ye göre YBS'nin evrensel olarak kabul edilmiş bir tanımı bulunmamaktadır. Bu doğrultuda, yıllar boyunca farklı perspektiflerden YBS alanının farklı özelliklerine vurgulama yapan tanımlara rastlanmaktadır (Bensghir Kaya, 2002; Patterson, 2005; Nath ve Badgujar, 2013; AlMamary vd., 2013).

Holsapple (2008)'e göre, YBS alanının kimlik oluşumunu anlamanın alandaki bilgi birikiminin değerlendirilmesi ve entelektüel çekirdeğinin araştırılması ile mümkün olduğunu vurgulamıștır. Bilimetrik çalışmalar sayesinde belirlenen alanlar üzerine literatür madenciliği yapılabilir ve bu sayede araștırmacıların, ilgilendikleri alanda daha fazla bilgi birikimi elde edebilirler (Damar vd., 2018:327). Buradan yapılacak en önemli çıkarım, söz konusu iç gözlemin gerçekleștirilebilmesi için dönemsel olarak literatürün genel bir görünümünün ortaya konmasıdır. Bu amaçla, derinlemesine bilgiler sunan sistematik derlemeler ve incelemeler yapılabileceği gibi, bibliyometri, bilimetri gibi bilgi-belge yönetimi alanının sunduğu yöntemler kapsamında, temel ve gerekli durumlarda ileri istatistik analizlerle, farklı boyutlar üzerinden sıklıklar, eğilimler ve örüntüler ortaya çıkarılabilir.

YBS alanında bibliyometri ve ilişkili yöntemlerin uygulaması 1980'li yılların başına kadar uzanmakta olup ulaşılabilen en eski çalışmalar, Culnan (1986), Culnan (1987), Farhoomand (1987), Culnan ve Swanson, (1986) ve bu çalışmanın bir güncellemesi olan
Cheon ve diğerleri (1992) olmuştur. Bu çalışmalarda, genellikle üretilen makalelere ilişkin istatistiklere yer verilmiștir. Öte yandan, izleyen ylllarda, Cocosila ve diğerleri (2011), YBS alanının gelişimine yön veren ve pek çok araștırmanın tartışmaya açıldığı International Conference on Information Systems (ICIS), Pacific Asia Conference on Information Systems (PACIS) ve Administrative Sciences Association of Canada Annual Conference (ASAC) adlı akademik etkinliklerde sunulan bildirileri, bilimetri metodolojisinin sunduğu teknik ve araçlar aracilığı ile incelemiștir. YBS alanında ve bu alanın bileșenlerini oluşturan diğer konularda Cocosila ve diğerleri (2011)'nin çalışmasının kapsamı doğrultusunda yapılan pek çok güncel çalışmaya rastlamak mümkündür. Makalelerin ve bildirilerin yanı sıra YBS araştırmalarına ilişkin portföyde önemli paya sahip olan dergiler de yine aynı bakış açısı ve metodoloji ile mercek altına alınmıştır (de Carvalho Pereira vd., 2015; Merigó vd., 2018; Beydoun vd., 2019; La Paz vd., 2020; Kokol vd., 2018; Donthu vd., 2021; Islam ve Widen, 2021; Abedin vd., 2021).

Geçmişten günümüze yapılan tüm bu çalışmalar, ele alınan dönem içerisinde YBS ve ilişkili konularda öne çıkan yayınları, dergileri, yazarları, kurumları, ülkeleri, içerikleri, referansları ve eklenebilecek diğer boyutları özetleyerek, diğer bilimsel çalışmalara yön gösterecek, literatür araştırmalarını kolaylaştıracak pek çok bulgu sunmaktadır. Bu bağlamda Türkiye'de her geçen gün alandaki açılan lisans, yüksek lisans ve doktora programlarını, artan araştırmacı sayısı ile yönetim bilişim sistemleri disiplininin akademik üretkenlik ve uluslararası alan dergileri konusunda bir değerlendirmeye ihtiyacı vardır. Bu ihtiyaç alanın tüm sektörler için taşıdığı önem, mezunlarının alana etkisi ve ayrıca ulusal literatüre sıkışan araştırmacıların yerine uluslararası literatüre hakim ve bu yönde alana katkı sunan araştırmacı ihtiyacından da kaynaklandığı ifade edilebilir. Çalışma, Türkiye özelinde, SCImago listesinde yer alan uluslararası YBS dergileri üzerinde genel bir değerlendirme sunmayı, uluslararası 
Q1 dergilerin diğer alanlar ile ilişkileri ve dergilerin nitelikleri hakkında genel bir değerlendirmeyi ve Q1 dergilerde 2010 yılından günümüze Türkiye adresli makalelerin bibliyometrik analizini gerçekleştirmektedir. $\mathrm{Bu}$ sayede uluslararası nitelikteki dergilerde Türkiye'deki YBS alanında çalışan araştırmacılarımızın bilimsel üretkenliği değerlendirilmektedir.

Çalışma analizinde kullanılan veri seti, en önemli uluslararası bibliyometrik veritabanlarından birisi olan SCOPUS bibliyometrik veritabanından çekilmiştir. Analizlerin veri kaynağını, SCImago Journal and Country Rank bünyesinde siralamalarda yer alan uluslararası YBS dergileri oluşturmaktadır. $\mathrm{Bu}$ kapsamda Scopus üzerinden 104 uluslararası YBS Dergisi ile ilgili yayın türleri, dergi sayısının ülkelere göre dağılımı, dergilerin konulara göre dağılımı, temel alan ve mesleklere göre dağılımı, yayıncı kurumlar, endeks ve dil dağılımı gibi pek çok farklı boyutta istatistikler elde edilmiștir. Tüm bulgular eşliğinde, YBS alanında yayın yapan dergilerdeki Türkiye adresli araştırmacıların genel durumu değerlendirilmekte uluslararası dergilerdeki genel üretkenlik istatistikleri ile karşılaştırılarak, Türkiye'nin bu bağlamdaki mevcut durumu tartışmaya açılmaktadır. Ayrıca YBS alanının Türkiye' de gelişimine katkı sunan kişi, kurum veya fikirlere yer vererek bu alana bir gelecek vizyonu sunulmaktadır. Elde edilen bulgular ışığında Türkiye'deki YBS disiplinin daha iyi hale gelebilmesi için öneriler sunulmaktadır.

\section{SCOPUS VE SCIMAGO JOURNAL \& COUNTRY RANK}

SCImago Journal \& Country Rank, Elsevier firmasının sahip olduğu Scopus veritabanında yer alan bilgilerden geliştirilen dergileri ve ülke bilimsel göstergelerini içeren halka açık bir portaldır. Elsevier, 1880'de küçük bir yayıncı firma olarak Jacobus Robbers tarafindan Hollanda'nın Roterdam kentinde, dört iş adamı arkadaşıyla kurulmuştur (Elsevier, 2021). 2004 yılında ise Scopus projesi başlatılmıştır. Scopus özet bir veri tabanı olarak tasarlanmış ve çeşitli yayıncıların dergilerini ve kitaplarını barındırmaktadır. Scopus günümüzde yetmiş beş milyonun üzerinde kayıta sahip, 24.600 üzerinde aktif başlık, 194.000 üzerinde kitap ve 5.000 yayıncı ile faaliyetlerini sürdürmektedir. Sağlık bilimleri 7.468 bașlık ile \%25, fiziki bilimler 8.102 başlık ile \%27, yaşam bilimleri 4.883 başlık ile \%16, sosyal bilimler 9.692 başlık ile \%32'sini oluşturmaktadır (Scopus, 2021). Scopus, bilimsel dergiler, kitaplar ve konferans bildirileri gibi hakemli literatürün en büyük özet ve atıf veri tabanıdır. Bilim, teknoloji, tıp, sosyal bilimler, sanat ve beșeri bilimler alanlarında dünyanın araştırma çıktılarına kapsamlı bir genel bakıș sunan Scopus, araştırmaları izlemek, analiz etmek ve görselleştirmek için akıllı araçlar sunmaktadır. Scopus dünya çapında 3.000'den fazla akademik kurum, devlet kuruluşu ve kurumsal şirket tarafından kullanılmaktadır ve araştırma zekası portföyünü destekleyen ana veri kaynağı niteliği taşımaktadır (BlogScopus, 2021).

SCImago Journal \& Country Rank bilimsel alanları değerlendirmek ve analiz etmek için çaba sarf etmektedir. SCImago, SCImago Journal Rank (SJR) göstergesini yaygın olarak bilinen Google PageRank algoritmasına benzer bir algoritma kullanarak oluşturmuştur. SJR, SCImago dergi ve ülke sıralaması veya sinıflandırması anlamına gelmektedir. SJR, üç yıllık bir süre boyunca makale başına ağırlıklı atıfların bir dizinidir. Özellikle atıf bazlı göstergeler oldukça faydalı olmak ile beraber atıflar ve belgeler için tüm bilgiler Scopus bibliyometrik veritabanından elde edilmektedir. SCImago, Consejo Superior de Investigaciones Científicas (CSIC), University of Granada, Extremadura, Carlos III (Madrid) ve Alcalá de Henares'ten görselleștirme teknikleri aracılığıyla bilgi analizi, temsili ve geri alımına adanmış bir araştırma grubu tarafından geliştirilmiştir. Alıntı verileri, 5.000'den fazla uluslararası yayıncıdan gelen 34.100'den fazla kitaptan ve dünya çapında 239 ülkeden elde edilen ülke performans metriklerinden alınmıştır. Dergiler ayrı ayrı karşılaştırılabilir veya analiz edilebilir. Ülke sıralanabilir, karşılaştırılabilir veya ayrı ayrı analiz edilebilir. 
Dergiler konu alanına (27 ana tematik alan), konu kategorisine (313 belirli konu kategorisi) veya ülkelere göre gruplandırılabilir (SCImago, 2021). Bu konu kategorilerinden birisi de Issletme, Yönetim ve Muhasebe temel tematik alanında yer alan Yönetim Bilişim Sistemleri konu kategorisidir.

\section{YÖNTEM}

Çalıșma analizinde kullanılan veri seti, en önemli bibliyometrik veri tabanlarından birisi olan SCOPUS bibliyometrik veri portalından çekilmiştir. Analizlerin veri kaynağını, SCImago Journal and Country Rank (SCImago Journal Rank göstergesi, bilimsel dergilerin bilimsel etkisinin bir ölçüsüdür.) bünyesinde sıralamalarda yer alan uluslararası YBS dergileri (Q1, Q2, Q3, Q4 sinıflandırılmasında yer alan toplam 104 dergi) bulunmaktadır. SCImago Elsevier tarafından desteklenen Scopus bibliyometrik veri tabanını referans alan, buradaki dergileri inceleyen, dergi ve ülke sıralamaları ortaya koyan herkese açık bir portaldır. $\mathrm{Bu}$ kapsamda öncelikle, 104 uluslararası YBS Dergisi SCImago web sitesi aracılığ aracılığı ile Scopus indeksinde taranan SCImago tarafından YBS alanında sınıflandırılmıș uluslararası dergi yayıncılığı üzerine genel bir değerlendirme sunulmaktadır. Q1 dergi verileri bibliyometrik yöntemler ile analiz için Scopus üzerinden 2010-2021 döneminde YBS alanındaki Q1 dergilerdeki yayınlar için makro düzeyde analiz gerçekleştirilmiş ve bir değerlendirme sunulmuştur.

SCImago internet sitelerinin parametrik raporlar ile elde edilen veriler ile birlikte ilgili siteden alınan ek veriler Microsoft Excel ve Microsoft Power BI platformlarında geliștirilen tablo ve görseller yardımıyla analiz edilmiş ve raporlanmıştır. Ardından araştırmamızın odak noktasını oluşturan, Türkiye adresli yayınların YBS Q1 dergilerdeki yayın durumu hakkında detaylı analizler gerçekleştirilmiştir. İnceleme alanımız içinde olan 26 Q1 dergi, alanda ön planda yer alan araștırma ve tartışmaların gerçekleștirildiği dergilerdir. Pekala, ilgili dergilerde araștırmacıların en yoğun üzerinde durduğu konular nelerdir ve bu tartışmalar konusunda genel izlenime nasıl sahip olabiliriz? Tüm bu soruların cevapları için Şekil 1 üzerinde ifade edilen çalışma metodolojisi içinde cevap aranmıştır.

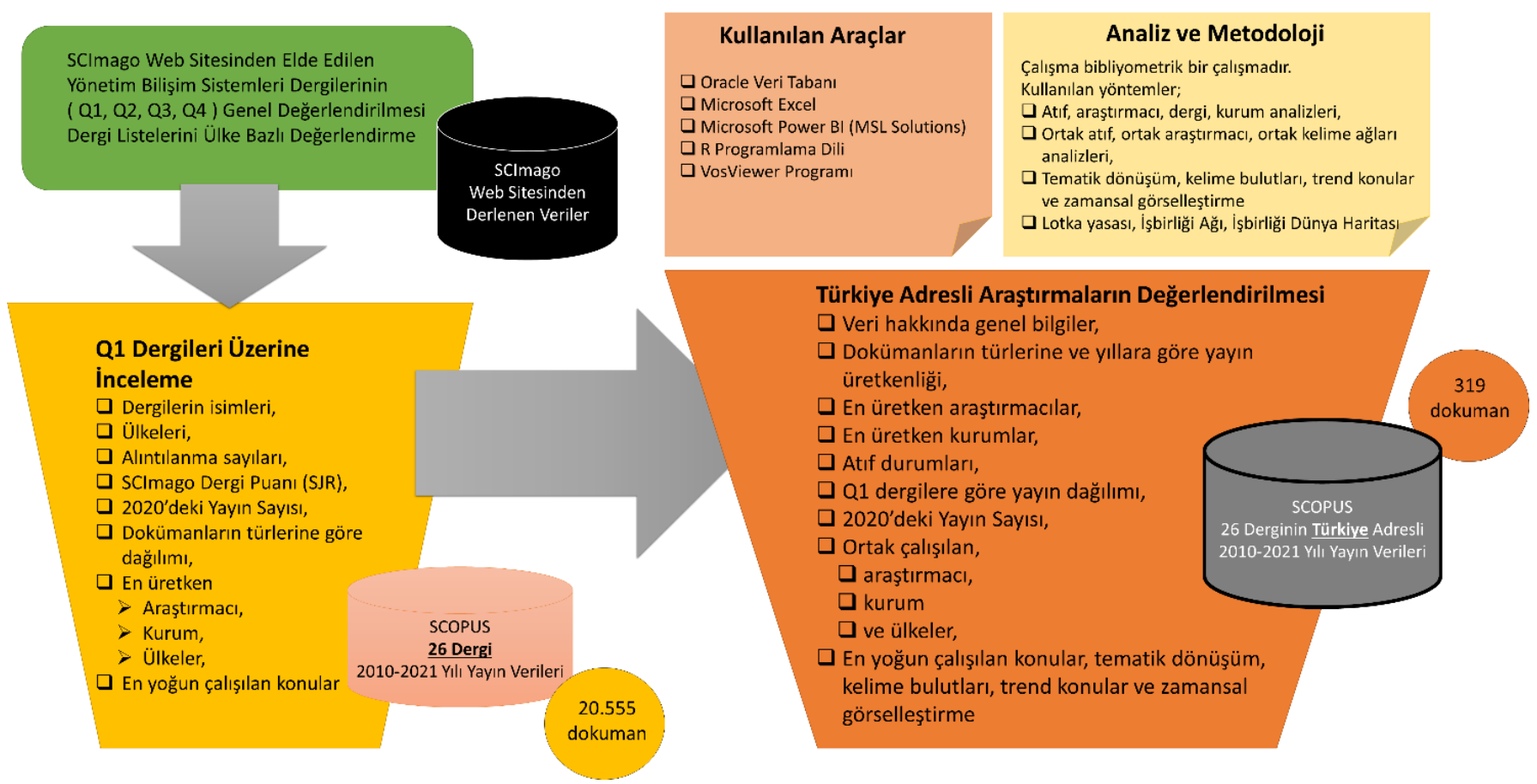

Şekil 1: Çalışma Metodolojisi 


\section{BULGULAR ve TARTIȘMA}

$\mathrm{Bu}$ başlık altında öncelikle Scopus veritabanı tarafından taranan ve Yönetim Bilişim Sistemleri alanındaki akademik çalıșmaları yayınlayan dergilerin sayıları, çeyreklik değerleri (Q), ülke ve bölge bazlı dağılımları derlenmiștir. Ardından çeyreklikler özelinde dergilerin durumları detaylı bir șekilde incelenmiştir. Ardından SCImago Q1 dergilerinde Türkiye adresli çalışmalara ve detaylı analizlerine yer verilmiştir. Araştırmacılar ve referans kaynaklar üzerine değerlendirmeler yapılmıştır. Ayrıca YBS alanındaki Türkiye adresli dergilerin durumuna kısaca yer verilerek bu dergilerin uluslararası alanda daha çok tanınır ve daha iyi dizinlerde taranmasının sağlanması için yapılması gerekenler konusunda öneriler sunulmuştur. Son olarak Türkiye'de YBS alanının kurulması ve gelişmesi için katkı veren ve çalışan kurum, kuruluş ve kişilere değinilmiștir.

\subsection{Scopus Tarafindan Taranan Yönetim Bilişim Sistemleri Dergileri Genel Durum}

ScimagoJR (2021) üzerinde Scimago Journal Rank (SJR)'a göre yönetim bilișim sistemleri alanında yer alan dergi sayısı 104'tür. SJR ilgili alanlardaki dergileri dört sinıfta gruplamaktadır. Bunlar çeyreklik olarak da adlandırılan Q1, Q2, Q3 ve Q4'tür ve bu çeyreklik grupları dergilerin Scimago Journal Rank atıf indekslerine göre oluşturulmaktadır. Q1'den Q4'e doğru gidildiğinde dergilerin alandaki etkileri (Dergideki çalıșmaların aldığı ortalama atıf sayıları düşmektedir.) azalmaktadır. Q1 sınıfındaki dergilerin alandaki en önemli dergiler olduğu, bilimsel etki ve yayın saygınlığı anlamındaki değerlerinin diğer dergilere göre daha fazla olduğu ayrıca ifade edilmesi gerekir.

Yönetim bilișim sistemleri alanındaki 104 adet dergi içinde Q1 dergi sayısı 26, Q2 dergisi 27, Q3 dergi sayısı 25 ve Q4 dergi sayısı ise 26'dır. 104 Yönetim Bilișim Sistemleri dergisinin bölgelere göre dağılımı; Batı Avrupa yaklaşı \%58 (Q1:17; Q2:16; Q3:15; Q4:10; Toplam:58), Kuzey Amerika \%28 (Q1:9; Q2:7; Q3:4; Q4:10; Toplam:30), Asya Bölgesi \%5 (Q2:2; Q3:2; Q4:2; Toplam:6), Doğu Avrupa \%4 (Q2:2; Q3:2; Q4:1; Toplam:5), Orta Doğu \%2 (Q3:1; Q4:2; Toplam:3), Afrika \%0,9 (Q4:2; Toplam:1) ve Latin Amerika \%0,9 (Q3:1; Toplam:1) şeklindedir. Ülkelere göre yönetim bilişim sistemleri alanındaki dergi dağılımları ise Șekil 2'de gösterilmiștir.

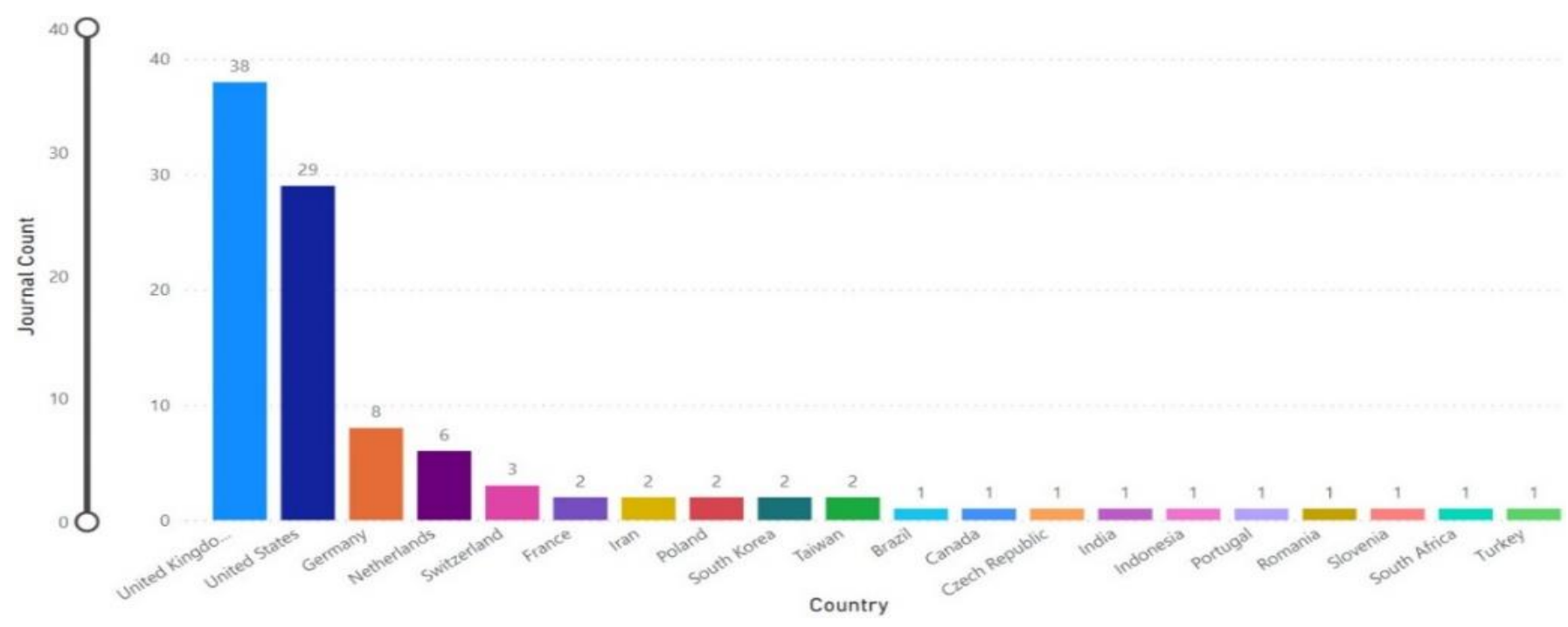

Şekil 2: Yönetim Bilişim Sistemleri Ülkelere Göre Dergi Sayıları

Q1, Q2, Q3 ve Q4 çeyrekliklerindeki dağılımları belirtilmiş şekilde ülke bazlı dergilerin toplam sayısına göre sıralama ise; Birleşik Krallık (Q1:12; Q2:9; Q3:11; Q4:6; Toplam:38), Amerika Birleşik Devletleri (Q1:9; Q2:6; Q3:4; 
Q4:10; Toplam:29), Almanya (Q1:1; Q2:4; Q3:2; Q4:1; Toplam:8), Hollanda (Q1:4; Q3:2; Toplam:6), İsviçre (Q2:2; Q4:1; Toplam:3), Fransa (Q4:2; Toplam:2), İran (Q3:1; Q4:1; Toplam:2), Polonya (Q2:1; Q3:1; Toplam:2), Güney Kore (Q2:1; Q4:1; Toplam:2), Tayvan (Q3:1; Q4:1; Toplam:2), Brezilya (Q3:1; Toplam:1), Kanada (Q2:1; Toplam:1), Çek Cumhuriyeti (Q4:1; Toplam:1), Hindistan (Q2:1; Toplam:1), Endonezya (Q3:1; Toplam:1), Portekiz (Q2:1; Toplam:1), Romanya (Q3:1; Toplam:1), Slovenya (Q2:1; Toplam:1), Güney Afrika (Q4:1; Toplam:1), Türkiye (Q4:1; Toplam:1), şeklindedir (Şekil 2). Batı Avrupa ve Kuzey Amerika yönetim bilişim sistemleri alanında yayıncılık faaliyetleri kapsamında toplamda 104 derginin $88 \quad(\% 84,62)$ 'ine sahiptir. $\mathrm{Bu}$ durum elbette Batı Avrupa ve Kuzey Amerika'daki ekonomik ve teknolojik imkan ve durum ile ilişkili olduğu da düşünülebilir. $\mathrm{Bu}$ ifadeyi yönetim bilişim sistemleri alanında yayıncılık faaliyetlerine en yoğun katkı sunan ülkeler değerlendirildiğinde de Birleşik Krallık, Amerika Birleşik Devletleri, Almanya, Hollanda, İsviçre, Fransa gibi ülkelerinin bulunması bu ifadeyi destekleyici bir bulgu olarak ifade edilebilir.

\subsection{Q1 Dergilerinde Genel Görünüm}

Tablo 2'de yönetim bilişim sistemleri alanındaki Scimago Journal Rank sistemine göre Q1 çeyrekliğinde yer alan 26 dergi verilmiştir. Yönetim bilişim sistemleri Q1 seviyesindeki dergilerin yönetim bilişim sistemleri hariç tutulduğunda 30 farklı alan ile ilişkide olduğunu göstermektedir. $\mathrm{Bu}$ alanlar yönetim bilişim sistemlerini de dahil ettiğimizde Tablo 1'deki gibi listelenebilir. Bu dergilerin 2020 yılı yayın sayıları, yayın periyodu ve yayıncısının ülkesi gibi pek çok bilgi Tablo 3 üzerinde paylaşılmaktadır.

Tablo 1: Q1 seviyesindeki dergilerin alan kodları ve açılkamaları

\begin{tabular}{|c|c|c|c|}
\hline Alan & Açılklama & Alan & Açıklama \\
\hline (A1) & Bilgisayar Bilimi ve Uygulamaları & (A17) & İnsan Bilgisayar Etkileșimi \\
\hline (A2) & Bilgi Sistemleri & (A18) & Finans \\
\hline$(\mathrm{A} 3)$ & Yönetim Bilişim Sistemleri & (A19) & Kütüphane ve Bilgi Bilimi \\
\hline (A4) & Bilgi Sistemleri ve Yönetimi & $(\mathrm{A} 20)$ & Ekonomi, Ekonometri ve Finans \\
\hline (A5) & \begin{tabular}{|l} 
Yönetim Bilimi ve \\
Araștırması
\end{tabular} & $(\mathrm{A} 21)$ & $\begin{array}{l}\text { Organizasyon Davranışları ve İnsan Kaynakları } \\
\text { Yönetimi }\end{array}$ \\
\hline$(\mathrm{A6})$ & Bilgisayar Ağları ve İletişim & $(\mathrm{A} 22)$ & Yapay Zeka \\
\hline (A7) & Yönetim ve Strateji & (A23) & Turizm, Eğence ve Konaklama Yönetimi \\
\hline (A8) & Simülasyon ve Modelleme & (A24) & Kamu Yönetimi \\
\hline (A9) & İstatistik, Olasılık ve Belirsizlik & (A25) & Sanat ve Beşeri Bilimler \\
\hline$(\mathrm{A} 10)$ & İnovasyon ve Teknoloji Yönetimi & (A26) & Gelişim ve Eğitim Psikolojisi \\
\hline$(\mathrm{A} 11)$ & Pazarlama & (A27) & Kültürel Çalışmalar \\
\hline$(\mathrm{A} 12)$ & Sistem ve Kontrol Mühendisliği & (A28) & Politika Bilimi ve Uluslararası Ilişkiler \\
\hline$(\mathrm{A} 13)$ & İşletme ve Uluslararası Yönetim & (A29) & Endüstri ve Üretim Mühendisliği \\
\hline$(\mathrm{A} 14)$ & Muhasebe & (A30) & Endüstriyel İlişkiler \\
\hline$(\mathrm{A} 15)$ & $\begin{array}{l}\text { Yönetim, İzleme-Denetim, Politika } \\
\text { ve Hukuk }\end{array}$ & (A31) & Yapı ve İnşaat \\
\hline$(\mathrm{A} 16)$ & Yazılım & & \\
\hline
\end{tabular}




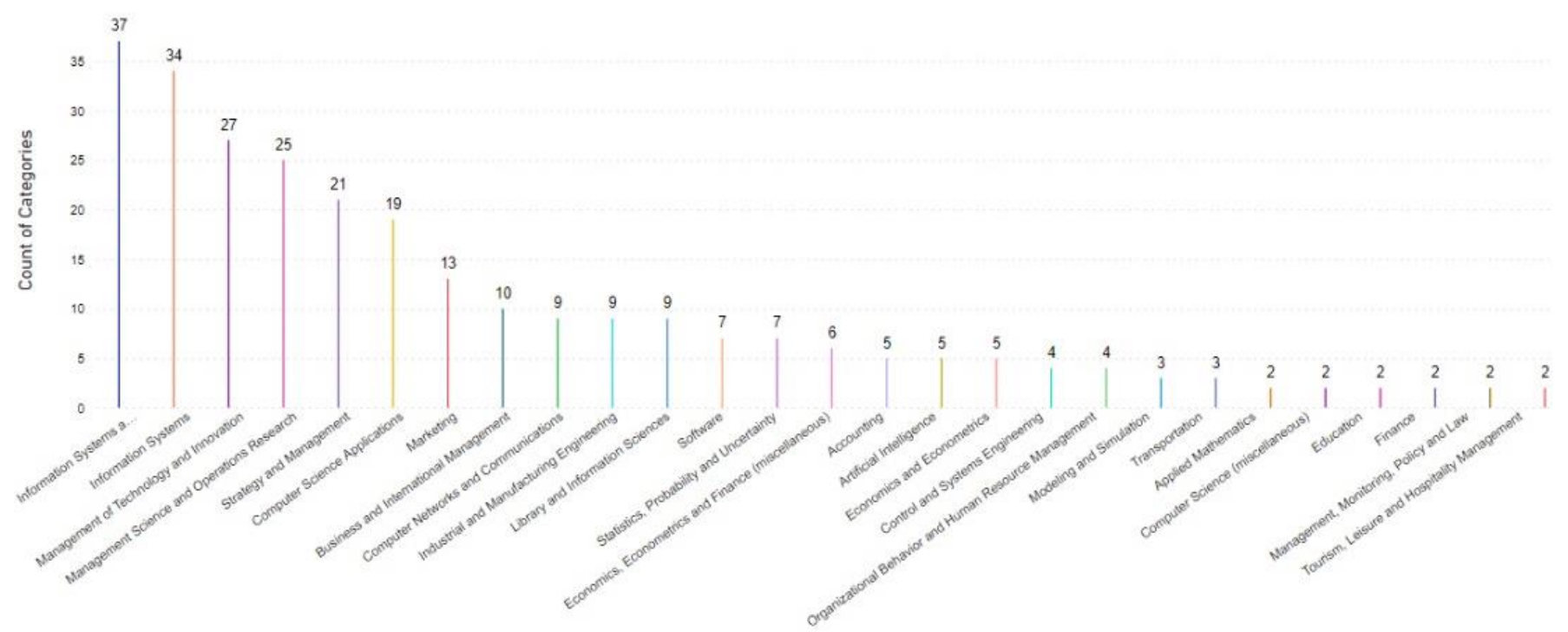

Şekil 3: Yönetim Bilişim Sistemleri Dergilerinin Yönetim Bilişim Sistemleri Harici İlişkili Olduğu Diğer Araştırma Alanları

Yönetim Bilişim Sistemleri alanındaki 104 derginin ilişkilendirildiği en yoğun üç alan sırasıyla; bilgi sistemleri ve yönetimi (f:37), bilgi sistemleri (f:34), inovasyon ve teknoloji yönetimi (f:27) şeklindedir (Şekil 3). Şekilde gösterilmeyen fakat ilişkili olan diğer alanlar sırasıyla; yapı ve inşaat (f:1), inşaat ve yapı mühendisliği (f:1), iletişim (f:1), algoritmalar teorisi ve matematik (f:1), bilgisayar görü ve örüntü tarama (f:1), kültürel çalışmalar (f:1), karar bilimleri (f:1), gelişim ve eğitim psikolojisi (f:1), e-öğrenme (f:1), elektrik ve elektronik mühendisliği (f:1), mühendislik (f:1), donanım ve mimari (f:1), insan ve bilgisayar etkileşimi (f:1), endüstriyel ilişkiler (f:1), hukuk (f:1), multidisipliner (f:1), siyaset bilimi uluslararası ilişkiler (f:1), kamu yönetimi (f:1), güvenlik araștırmaları (f:1), sinyal işleme (f:1), sosyoloji ve siyaset bilimi (f:1), teorik bilgisayar bilimi (f:1), șeklindedir. SCOPUS tarafından taranan ve kendisini yönetim bilişim sistemleri alanıyla ilişkilendirmiş Q1 dergilerde, kamu yönetimi, hukuk, endüstriyel ilişkiler, siyaset bilimi uluslararası ilişkiler, sosyoloji ve siyaset bilimi, gelişim ve eğitim psikolojisi gibi ilk bakıșta YBS ile ilişkisi doğrudan kurulmakta zorluk çekilen alanlar ile alandaki yayıncılık faaliyeti yürüten dergilerin ilişkilendiği görülmektedir.
Q1 sınıfındaki dergilerin alandaki en önemli dergiler olduğu, bilimsel etki ve yayın prestiji anlamındaki değerlerinin diğer dergilere göre daha fazla olduğu ayrıca ifade edilmesi gerekir ve Tablo 2 üzerinde de görüleceği üzere bu dergilerin sayısı 26'dır. İlgili dergiler geçmişten bugüne yıl kısitlaması olmadan değerlendirildiğinde doküman sayısının 38.571 adet olduğu görülmektedir. Dokuman sayılarına göre dağılım; makale (f:34.885), editör dokümanı (f:1.288), derleme (f:967), bildiri (f:608) şeklindedir. 2010-2021 yılları arasında ilgili dergilerde üretilen dokuman sayısı ise 20.545 'tir. İlgili yıllar arasında Q1 dergilerde üretilen makale $(f: 19.074)$, editör dokumanı (f:607), derleme (f:425), bildiri $(f: 195)$ şeklindedir. İlgili dergilerin yayın dili İngilizce'dir. Tüm dokumanlar İngilizce dilinde yazılmıştır. $\mathrm{Bu}$ durum Türkiye'deki araştırmacılar için İngilizce'nin önemini ve uluslararası tanınırlık ve bilimsel üretkenlik için kritik öneminin bir başka göstergesi olarak ifade edilebilir. 2010-2021 yılları arasında Q1 dergilerde üretilen dokümanların konu alanına göre dağılımı ise; işletme, yönetim ve muhasebe (f:19.026), bilgisayar bilimleri (f:14.318), karar bilimleri (f:13.259), sosyal bilimler (f:3.292), ekonomi, mühendislik (2.420), psikoloji $(f: 1.708)$, sanat ve beșeri bilimler $(f: 1.708)$, ekonometri ve finans (550), matematik (f:437), çevre bilimleri (f:397), şeklindedir. 
Tablo 2: MIS Alanında Q1 Dergi Listesi (Scimago Journal Rank)

\begin{tabular}{|c|c|c|c|c|c|c|c|}
\hline \# & Başlık & SJR & \begin{tabular}{c|} 
H- \\
indeks
\end{tabular} & TDS2020 & AD2 & Ülke & Kategoriler \\
\hline 1 & $\begin{array}{l}\text { MIS Quarterly: Management } \\
\text { Information Systems }\end{array}$ & 5,283 & 230 & 60 & 7,97 & ABD & A1 (Q1); A2 (Q1); A3 (Q1); A4 (Q1) \\
\hline 2 & $\begin{array}{lll}\text { Journal of Supply } & \text { Chain } \\
\text { Management } & & \\
\end{array}$ & 3,75 & 92 & 27 & 7,78 & ABD & A20 (Q1); A2 (Q1); A3 (Q1); A11 (Q1) \\
\hline 3 & Information Systems Research & 3,507 & 159 & 70 & 6,09 & ABD & A6 (Q1); A2 (Q1); A4 (Q1); A19 (Q1); A3 (Q1) \\
\hline 4 & Information and Organization & 3,298 & 61 & 15 & 7,79 & İngiltere & $\begin{array}{l}\text { A2 (Q1); A19 (Q1); A3 (Q1); A10 (Q1); A21 } \\
\text { (Q1) }\end{array}$ \\
\hline 5 & $\begin{array}{l}\text { Journal of Strategic Information } \\
\text { Systems }\end{array}$ & 3,133 & 88 & 24 & 12,45 & Hollanda & A2 (Q1); A4 (Q1); A3 (Q1) \\
\hline 6 & \begin{tabular}{|l|l|} 
Journal of Management \\
Information Systems
\end{tabular} & 3,073 & 144 & 44 & 8,32 & $\mathrm{ABD}$ & A1 (Q1); A4 (Q1); A3 (Q1); A5 (Q1) \\
\hline 7 & $\begin{array}{l}\text { International Journal } \\
\text { Information Management }\end{array}$ & 2,77 & 114 & 224 & 16,16 & İngiltere & $\begin{array}{l}\text { A22 (Q1); A6 (Q1); A2 (Q1); A4 (Q1); A19 } \\
\text { (Q1); A3 (Q1); A11 (Q1) }\end{array}$ \\
\hline 8 & Information and Management & 2,147 & 162 & 130 & 8,94 & Hollanda & A2 (Q1); A4 (Q1); A3 (Q1) \\
\hline 9 & $\begin{array}{l}\text { Journal of Hospitality Marketing } \\
\text { and Management }\end{array}$ & 1,708 & 53 & 55 & 6,97 & $\mathrm{ABD}$ & A3 (Q1); A11 (Q1); A23 (Q1) \\
\hline 10 & \begin{tabular}{|l|} 
Public Management Review \\
\end{tabular} & 1,622 & 68 & 158 & 5,39 & İngiltere & A3 (Q1); A10 (Q1); A24 (Q1) \\
\hline 11 & Knowledge-Based Systems & 1,587 & 121 & 716 & 9,42 & Hollanda & A22 (Q1); A4 (Q1); A3 (Q1); A16 (Q1) \\
\hline 12 & Decision Support Systems & 1,564 & 151 & 115 & 7,04 & Hollanda & $\begin{array}{l}\text { A25 (Q1); A26 (Q1); A2 (Q1); A4 (Q1); A3 } \\
\text { (Q1) }\end{array}$ \\
\hline 13 & $\begin{array}{l}\text { European Journal of Information } \\
\text { Systems }\end{array}$ & 1,426 & 108 & 62 & 4,71 & İngiltere & A2 (Q1); A4 (Q1); A19 (Q1); A3 (Q1) \\
\hline 14 & $\begin{array}{l}\text { International Entrepreneurship } \\
\text { and Management Journal }\end{array}$ & 1,338 & 55 & 108 & 6,12 & $\mathrm{ABD}$ & A3 (Q1); A10 (Q1) \\
\hline 15 & \begin{tabular}{|l|} 
Information Society \\
\end{tabular} & 1,133 & 75 & 25 & 4,48 & İngiltere & A27 (Q1); A2 (Q1); A3 (Q1); A28 (Q1) \\
\hline 16 & $\begin{array}{|lr|}\text { International Journal of Systems } \\
\text { Science: Operations and } \\
\text { Logistics }\end{array}$ & 1,117 & 21 & 52 & 6,55 & İngiltere & A2 (Q1); A4 (Q1); A3 (Q1); A5 (Q1) \\
\hline 17 & \begin{tabular}{|l|} 
Journal of Contingencies and \\
Crisis Management
\end{tabular} & 1,007 & 51 & 54 & 4,62 & İngiltere & A3 (Q1); A15 (Q1) \\
\hline 18 & \begin{tabular}{|l|}
$\begin{array}{l}\text { Industrial Management and Data } \\
\text { Systems }\end{array}$ \\
\end{tabular} & 0,994 & 103 & 133 & 4,42 & İngiltere & $\begin{array}{l}\text { A1 (Q1); A29 (Q1); A30 (Q1); A3 (Q1); A7 } \\
\text { (Q1) }\end{array}$ \\
\hline 19 & \begin{tabular}{|lr} 
International Journal of \\
Accounting Information Systems
\end{tabular} & 0,897 & 53 & 21 & 5,56 & $\mathrm{ABD}$ & A18 (Q1); A4 (Q1); A3(Q1); A14 (Q2) \\
\hline 20 & \begin{tabular}{|l|} 
Construction Management and \\
Economics
\end{tabular} & 0,88 & 94 & 75 & 3,8 & İngiltere & A31 (Q1); A29 (Q1); A3 (Q1) \\
\hline 21 & \begin{tabular}{|l|} 
Journal of Information Systems \\
\end{tabular} & 0,859 & 33 & 34 & 1,53 & $\mathrm{ABD}$ & $\begin{array}{l}\text { A17 (Q1); A2 (Q1); A4 (Q1); A3 (Q1); A10 } \\
\text { (Q1); A16 (Q1); A14 (Q2) }\end{array}$ \\
\hline 22 & $\begin{array}{l}\text { International Journal of Logistics } \\
\text { Research and Applications }\end{array}$ & 0,802 & 33 & 83 & 4,1 & İngiltere & $\begin{array}{l}\text { A13 (Q1); A1 (Q1); A2 (Q1); A3 (Q1); A12 } \\
\text { (Q2); A10 (Q2); A5 (Q2); A7 (Q2) }\end{array}$ \\
\hline 23 & $\begin{array}{l}\text { Data Base for Advances in } \\
\text { Information Systems }\end{array}$ & 0,797 & 57 & 26 & 1,7 & ABD & A6 (Q1); A3 (Q1) \\
\hline 24 & \begin{tabular}{|l|l|} 
Journal of the Operational \\
Research Society
\end{tabular} & 0,753 & 108 & 299 & 2,65 & İngiltere & $\begin{array}{l}\text { A3 (Q1); A5 (Q2); A11 (Q2); A8 (Q2); A9 (Q2); } \\
\text { A7 (Q2) }\end{array}$ \\
\hline 25 & \begin{tabular}{|lcc|} 
Journal of & \multicolumn{2}{c|}{ Humanitarian } \\
Logistics and & Supply & Chain \\
Management & & \\
\end{tabular} & 0,695 & 25 & 25 & 3,2 & İngiltere & A3 (Q1); A5 (Q2) \\
\hline 26 & $\begin{array}{|lr|}\begin{array}{l}\text { Computational Management } \\
\text { Science }\end{array} & \\
\end{array}$ & 0,683 & 34 & 28 & 1,42 & Almanya & A2 (Q1), A3 (Q1) \\
\hline
\end{tabular}

Yıllara göre Q1 dergilerindeki 2010-2021 döneminde yayınlanan dokuman sayıları; üretkenlik 2021 (f:2.484), 2020 (f:2.478), 2019 (f:1.825), 2018 (f:1.707), 2017 (f:1.661), 2016 $(f: 1.608), 2015$ (f:1.557), 2014 (f:1.599), 2013 (f:1.576), 2012 (f:1.477), 2011 (f:1.353), 2010 (f:1.220) şeklindedir. Ülke bazlı değerlendirildiğinde ise; Amerika Birleşik Devletleri (f:291), Çin (f:4.679), Birleşik Krallık (f:2.384), Avustralya (f:1.333), İspanya (f:1.089), Kanada (f:1.073), Tayvan (f:937), Hong Kong (f:907), Almanya (f:797), Güney 
Kore (f:686), Hollanda (f:648), Fransa (f:631), İtalya (f:594), Hindistan (f:591), Singapur $(f: 489)$, İsveç (f:434), İran ( $f: 336)$, Finlandiya (f:330), Türkiye (f:319), Danimarka (f:310) şeklindedir. Türkiye, İran ve Finlandiya'nın ardından 319 araștırma ile 19. sırada yer almaktadır.

Bilindiği üzere bilimsel dokumanlar sürdürülen araştırma projelerinin çıktılarıdır. $\mathrm{Bu}$ araştırmalar da belirli kurum veya kuruluşlarca desteklenmektedir. Bu alanda uluslararası Q1 dergilerinde yayınlanmaya hak bulan dokümanlara en yoğun destek veren ilk on kurum sırasıyla şu șekildedir: Çin Ulusal Doğa Bilimleri Vakfi (f:3.218), Çin Halk Cumhuriyeti Eğitim Bakanlığı (f:663), Merkezi Üniversiteler için Temel Araştırma Fonları (f:544), Ulusal Bilim Vakfi (f:439), Avrupa Komisyonu (f:387), Maliye Bakanlığı (f:383), Çin Halk Cumhuriyeti Bilim ve Teknoloji Bakanlı̆̆ (f:280), Çin Ulusal Anahtar Araștırma ve Geliștirme Programı (f:274), Çin Doktora Sonrası Bilim Vakfı (f:210), Avrupa Bölgesel Kalkınma Fonu (f:206).

Q1 dergilerinde 2010-2021 yılları arasında ürettikleri yayınlar ile en yoğun katkı sunan ilk yirmi kurum ise șu șekildedir: Hong Kong Politeknik Üniversitesi (f:288), Hong Kong Şehir Üniversitesi (f:267), Çin Eğitim Bakanlı̆̆ (f:248), Singapur Ulusal Üniversitesi (f:216), Xi'an Jiaotong Üniversitesi (f:207), Tsinghua Üniversitesi (f:197), Georgia Eyalet Üniversitesi (f:183), Harbin Teknoloji Enstitüsü (f:179), Universidad de Granada (f:176), Çin Bilimler Akademisi (f:171), Arizona Eyalet Üniversitesi (f:154), Sichuan Üniversitesi (f:152), UNSW Sidney (f:150), Texas Austin Üniversitesi (f:145), Arizona Üniversitesi (f:143), Maryland Üniversitesi College Park (f:142), Nanyang Teknoloji Üniversitesi (f:141), Çin Bilim ve Teknoloji Üniversitesi (f:141), Huazhong Bilim ve Teknoloji Üniversitesi (f:139), Temple Üniversitesi (f:136).

Tablo 3 üzerinde Q1 dergilere en yoğun katkı sunan araştırmacıların kurumları, bu kurumların bulunduğu ülke, üretmiş oldukları makale ve bu makalelerden alınan atıf sayısı sunulmaktadır. En yoğun araştırma yapan ilk beș araștırmacl; Fujita, H. (f:81), Xu, Z. (f:50), Li, T. (f:42), Venkatesh, V. (f:40), Lowry, P.B. (f:39) şeklindedir.

Tablo 3: Q1 Dergilerde En Yoğun Doküman Üreten Araștırmacılar

\begin{tabular}{|l|l|r|r|l|l|}
\hline Sıra & \multicolumn{1}{|c|}{ Araştırmacı } & Dokuman Sayıs & Atıf Sayıs & \multicolumn{1}{|c|}{ Kurumu } & Ülkesi \\
\hline 1 & Fujita, H. & 81 & 4.245 & Iwate Prefectural Universitesi & Japonya \\
\hline 2 & Xu, Z. & 50 & 3.477 & Sichuan Universitesi & Çin \\
\hline 3 & Li, T. & 42 & 1.135 & Southwest Jiaotong Universitesi & Çin \\
\hline 4 & Venkatesh, V. & 39 & 7.800 & Arkansas Üniversitesi & ABD \\
\hline 5 & Lowry, P.B. & 2.638 & Virginia Politeknik Enstitüsü ve Eyalet Üniversitesi & ABD \\
\hline 6 & Herrera, F. & 38 & 1.904 & Granada Üniversitesi & İspanya \\
\hline 7 & Zwass, V. & 38 & 253 & Fairleigh Dickinson Üniversitesi & ABD \\
\hline 8 & Kauffman, R.J. & 35 & 1.033 & Singapur Yönetim Üniversitesi & Singapur \\
\hline 9 & Rai, A. & 35 & 1.877 & Georgia Eyalet Üniversitesi & ABD \\
\hline 10 & Grover, V. & 34 & 3.015 & Clemson Üniversitesi & ABD \\
\hline 11 & Pedrycz, W. & 34 & 959 & Alberta Üniversitesi & ABD \\
\hline 12 & Benbasat, I. & 33 & 2.689 & British Columbia Üniversitesi & Kanada/Türkiye \\
\hline 13 & Pan, S.L. & 32 & 1.217 & UnSW Sidney & Avustralya \\
\hline 14 & Gupta, A. & 31 & 1.177 & Minnesota Twin Cities Üniversitesi & ABD \\
\hline 15 & Herrera-Viedma, E. & 31 & 2.204 & Granada Üniversitesi & İspanya \\
\hline 16 & Zhao, X. & 31 & 422 & China Europe International Business School & Çin \\
\hline 17 & Agarwal, R. & 30 & 2.825 & Maryland Üniversitesi, College Park & Avustralya \\
\hline 18 & Loosemore, M. & 30 & 448 & UnSW Sidney & Avustralya \\
\hline 19 & Rao, H.R. & 29 & 1.580 & Buffalo Üniversitesi, New York Eyalet Üniversitesi & ABD \\
\hline 20 & Whinston, A.B. & 29 & 921 & Teksas Austin Üniversitesi & ABD \\
\hline
\end{tabular}

Tablo 3'de on ikinci sırada yer alan Prof. Dr. Izak Benbasat, aslında tüm zamanlardaki bilimsel üretkenlik dikkate alındığında 91 çalışma ile Fujita. H. (f:95) ardından bilimsel üretkenlik ve alana katkı veren en önemli ikinci bilim insanı olarak karşımıza çıkmaktadır. Prof. 
Dr. Izak Benbasat, British Columbia Üniversitesi Sauder School of Business'ta çalışmakta ve bilgi sistemleri ve yönetim bilişim sistemleri alanlarında en seçkin araştırmacılar arasında yer alan Türk ve Kanadalı bilim insanıdır (Benbasat, 2021). YBS disiplinine önemli katkılar sunmuş ve alana yön vermiş önemli araştırmacılardan birisidir (Benbasat ve Zmud, 2003; Moore ve Benbasat, 1991; Benbasat vd., 1987). Prof. Dr. Izak Benbasat Google Scholar'a göre yıllık ortalama dört bin üzerinde yeni atıf almakta iken toplamda ise 25.139 atıf almış, Türkiye'nin YBS akademi diasporasının en önemli isimlerinden birisi olarak görünmektedir. Prof. Dr. Izak Benbasat Türk YBS araştırmacıları için iyi bir rol model ve Türkiye'deki YBS disiplininden mezun bir araștırmacının uluslararası alanda nerelere gelebileceği üzerine güzel bir örnek olarak karşımıza çıkmaktadır.

Özdağoğlu ve diğerleri (2020) çalışmalarında, toplumların, geleceklerine, yükseköğretim kurumlarının yön vereceğine olan inançları artarken, bu durum, kurumlardan beklenen eğitim ve hizmet kalitesi düzeyini de aynı doğrultuda artırdığını ifade etmiştir. Yükseköğretim kurumlarının nitelikli insan kaynaklarının yetiștirildiği kurumlardır ve bu bağlamda mezunların ve öğrencilerin kariyer süreçlerinin etkinleştirilmesi önemli bir konudur (Damar vd., 2015:90). Dünyada önde gelen üniversiteler, mezunları ile etkileşim halinde bulunmayı kurum iç politika haline getirmişlerdir. Ülkenin en değerli kaynakları olan yükseköğretim öğrencilerinin geleceğin nitelikli işgücü olduğunu ve bu işgücüne şekil verecek, nitelik ve yetkinlik kazandıracak ise öğretim üyeleri olduğu aşikardır (Damar vd., 2021). Burada mezunların etkisi ve araştırma üniversiteleri için yurt dışı doktora yapmanın önemi (Damar vd., 2020:119), öğrencilerin lisans öğrenimleri sırasında öğretim üyeleri ve onların bağlantıları aracılığı ile desteklenmesinin önemi de ortaya çıkmaktadır.

Tablo 3 için aynı zamanda Türkiye'deki araştırmacılar için yüksek lisans veya doktora eğitimi yanında doktora sonrası araştırmaları sürdürmek için referans nitelikte olduğunu belirtmek gerekmektedir. Özellikle Researchgate veya Linkedin gibi akademik paylaşım veya kariyer siteleri üzerinden bu araștırmacıları takip etmeleri hatta iletişime geçmeleri önerilebilir. Ayrıca, bu araştırmacıların alandaki en önemli dergilerde bilimsel çalışmalar sunduğu ve alana yön verdikleri dikkate alınmalı, araştırmacıların çalıștıkları alanlar ile örtüşmesi durumunda alandaki güncel gelişmeleri takip etmek için ilgili araştırmacıların önemli bir referans kaynak olacağı unutulmamalıdır.

İnceleme alanımız içinde olan 26 adet Q1 dergi, alanda ön planda yer alan araștırma ve tartışmaların gerçekleştirildiği dergilerdir. Pekala, ilgili dergilerde araştırmaciların en yoğun üzerinde durduğu konular nelerdir ve bu tartışmalar konusunda genel izlenime nasıl sahip olabiliriz? Bu sorunun cevabı; bilimsel dokümanların ilgili dergiler ve okuyucunun ilgisi için etiketlenmesi ve konumlandırılmasına hizmet eden anahtar kelimelerdir. Tablo 4'te 26 adet Q1 dergide 2010-2021 yılları arasinda yayınlanan eserlerin en yoğun etiketlendiği ilk 100 İngilizce anahtar sözcük verilmiștir. İngilizce verilmesinin nedeni özellikle bilgisayar terimlerinde ve kavramlarda araştırmacılara çeviri yaparken farklı ve kavram karmaşasına yol açabilecek kelime örüntüleri ile belirsizlik oluşturulmasından kaçınma arzusudur. Q1 dergilerde üretilen çalışmalarda en yoğun kullanılan anahtar kelimeler; karar verme, karar destek sistemleri, karar teorileri, karar ağaçları, oyun teorisi, karar vericiler, karar verme süreci, karar destekleri, konularında en yoğun çalışmasının aslında toplam çalışmanın yaklaşık \%25'ine karşılık gelmektedir. İlgili alanda en yoğun çalışan kurumlar; Sichuan Üniversitesi (f:67), Çin Milli Eğitim Bakanlığ (f:49), Hong Kong Politeknik Üniversitesi (f:47); Granada Üniversitesi (f:45); Hong Kong Şehir Üniversitesi $(f: 34)$ șeklindedir. Bu alanda önceleri ABD üniversiteleri daha ön planda olduğu görülürken son yıllarda Çin üniversitelerinin ilgili alanda ön plana çıktığl, 
ABD’yi ikinci sıraya ittiği görülmektedir. İlgili alanda en önemli beş araştırmacı sırasıyla; Xu, Z. (f:41; Sichuan Üniversitesi), Fujita, H. (f:28; Iwate Prefectural Üniversitesi), Delen, D. (f:18;
Oklahoma Devlet Üniversitesi), Liao, H. (f:18; Sichuan Üniversitesi), Herrera-Viedma, E. (f:15; Granada Üniversitesi) şeklindedir.

Tablo 4: Q1 Dergilerde Üretilen Çalıșmalarda Kullanılan İlk 100 İngilizce Anahtar Kelime

\begin{tabular}{|c|c|c|c|c|c|}
\hline Sira & Anahtar Kelime (f) & Sira & Anahtar Kelime (f) & Sira & Anahtar Kelime (f) \\
\hline 1 & Decision Making (1.686) & 35 & Regression Analysis (366) & 69 & Game Theory (242) \\
\hline 2 & Information Systems (1.199) & 36 & Learning Algorithms (361) & 70 & Online Systems (242) \\
\hline 3 & Social Networking (online) (1.106) & 37 & Efficiency (354) & 71 & Heuristic Algorithms (240) \\
\hline 4 & Sales (1.039) & 38 & Feature Extraction (352) & 72 & Operations Research (239) \\
\hline 5 & Commerce (897) & 39 & Economics (351) & 73 & Fuzzy Sets (229) \\
\hline 6 & Artificial Intelligence (867) & 40 & Innovation (350) & 74 & Information Analysis (229) \\
\hline 7 & Data Mining (829) & 41 & Profitability (338) & 75 & Design (227) \\
\hline 8 & Decision Support Systems (792) & 42 & Managers (330) & 76 & Information Science (223) \\
\hline 9 & Design/methodology/approach (732) & 43 & Software Engineering (330) & 77 & Decision Trees (222) \\
\hline 10 & Information Management (678) & 44 & Scheduling (326) & 78 & Crisis Management (217) \\
\hline 11 & Learning Systems (671) & 45 & Clustering Algorithms (321) & 79 & Evolutionary Algorithms (217) \\
\hline 12 & Forecasting (650) & 46 & Deep Learning (319) & 80 & Uncertainty Analysis (217) \\
\hline 13 & Classification (of Information) (643) & 47 & Information Technology (317) & 81 & Quality Control (215) \\
\hline 14 & Optimization (639) & 48 & Neural Networks (316) & 82 & Structural Equation Modeling (214) \\
\hline 15 & Costs (630) & 49 & Decision Theory (314) & 83 & Least Squares Approximations (211) \\
\hline 16 & Knowledge Management (626) & 50 & Websites (303) & 84 & Outsourcing (211) \\
\hline 17 & Knowledge Based Systems (531) & 51 & Benchmarking (301) & 85 & Performance (211) \\
\hline 18 & Electronic Commerce (529) & 52 & Data Envelopment Analysis (296) & 86 & Customer Satisfaction (210) \\
\hline 19 & Semantics (514) & 53 & Integer Programming (288) & 87 & $\begin{array}{l}\text { Management Information Systems } \\
(209)\end{array}$ \\
\hline 20 & Behavioral Research (504) & 54 & Big Data (287) & 88 & Construction (207) \\
\hline 21 & Research (493) & 55 & Industry (283) & 89 & Computer Networks (205) \\
\hline 22 & Construction Industry (489) & 56 & Recommender Systems (272) & 90 & Security Of Data (203) \\
\hline 23 & Social Media (488) & 57 & Iterative Methods (268) & 91 & Classification (202) \\
\hline 24 & Project Management (475) & 58 & Health Care (265) & 92 & Rough Set Theory (199) \\
\hline 25 & Competition (469) & 59 & Marketing (264) & 93 & $\begin{array}{l}\text { Natural Language Processing Systems } \\
(197)\end{array}$ \\
\hline 26 & Supply Chains (469) & 60 & Stochastic Systems (263) & 94 & Case Study (196) \\
\hline 27 & Surveys (468) & 61 & Human Resource Management (261) & 95 & Information Dissemination (195) \\
\hline 28 & Investments (449) & 62 & Support Vector Machines (261) & 96 & Sustainable Development (192) \\
\hline 29 & Economic And Social Effects (430) & 63 & Manufacture (259) & 97 & Multiobjective Optimization (189) \\
\hline 30 & Supply Chain Management (418) & 64 & Risk Management (257) & 98 & Consumer Behavior (186) \\
\hline 31 & Information Use (410) & 65 & Trust (255) & 99 & Simulation (183) \\
\hline 32 & Risk Assessment (387) & 66 & Genetic Algorithms (253) & 100 & Feature Selection (179) \\
\hline 33 & Machine Learning (375) & 67 & Finance (251) & & \\
\hline 34 & Algorithms (371) & 68 & Sentiment Analysis (243) & & \\
\hline
\end{tabular}

İlk beș içerisinde bir bașka Türk akademisyen ve uluslararası alanda YBS disiplininde ön plana çıkmış bir başka Türk araştırmacı karşımıza çıkmaktadır. Prof. Dr. Dursun Delen, lisans eğitimini İstanbul Teknik Üniversitesi'nde tamamlamış, yüksek lisans eğitimini Yıldız Teknik Üniversitesi ve doktorasını Oklahoma Devlet Üniversitesi'nde tamamlayıp aynı kurumda uzun yıllar çalışmıştır. Prof. Dr. Dursun Delen, karar bilimi üzerinde alanın en önemli bilim insanlarından birisidir. Gerçekleștirdiği bilimsel çalışmalarda Türkiye'deki üniversitelerdeki araştırmacılar ile yoğun ișbirliği yaptığı ayrıca görülmektedir (Bastı vd., 2015; Oztekin vd., 2013). Bu durum Damar ve diğerleri (2020:119)'nin yurtdışı doktora eğitiminin ulusal yükseköğretim sistemine ve ulusal akademide olumlu etki yapacağı tezini destekleyen bir bulgudur.

YBS alanında faaliyet gösteren 26 dergi odaklandıkları alanlar, kullanılan anahtar kelime yoğunlukları gibi çeşitli parametrelere göre değerlendirildiğinde YBS disiplininin ilişkili olduğu alan çeşitliliği ve alanlar arasındaki baskın disiplinler de net bir şekilde 
görülebilmektedir. Ayrıca bu alanlar, Culnan ve Swanson (1986)'ın bundan neredeyse kırk yıl önce yaptığı çalışma ile benzerlik göstermektedir. İlgili araştırmacılar, YBS için, bu durumu alanın multidisipliner bir yapıda olmasını doğasından ve kuruluş zamanlarındaki araștırmacı dokusuna bağlamakta, alanın ilk başlarda yönetim ve bilgisayar bilimleri alanındaki araştırmacılar ile inşa edildiğini ifade etmişlerdir. Elbette yoğunlaşmanın fazla olduğu bilgi sistemleri ve yönetimi, bilgi sistemleri, teknoloji ve inovasyon yönetimi, yönetim bilimi ve yöneylem araştırması, bilgisayar ağları ve iletişim, strateji ve yönetim, modelleme ve simülasyon, istatistik, olasılık ve belirsizlik, pazarlama, işletme ve sistem mühendisliği, işletme ve uluslararası yönetim gibi araştırma alanları, yönetim bilișim sistemleri araştırmacılarının yoğunlaștığı alanlar olarak da belirtmekte fayda vardır.

\subsection{SCImago Q1 Dergilerinde Türkiye Adresli Çalışmalar}

Q1 dergilerinde geçmişten bugüne yıl kısıtlaması olmadan elde edilen doküman sayısı 38.571'dir ve Türkiye 474 dokuman ile (makale:457, derleme:9, bildiri:3, not:2, editör dökumanı:1, hata dokumanı:1, mektup:1) ilgili dergilerde yayın üretkenliği açısından Finlandiya'nın ardından 18. sırada yer almaktadır. 2010-2021 yılları arasında ilgili dergilerde üretilen Türkiye adresli dokuman sayısı ise 319 (makale:311, derleme:7, editör dökumanı:1)'dur. Tablo 5 üzerinde ilgili veriler hakkında genel bilgilere yer verilmiștir.

Tablo 5: Veri Hakkında Genel Bilgiler

\begin{tabular}{|c|c|}
\hline Açıklama & Sonuç \\
\hline Zaman aralığ & 2010:2021 \\
\hline Kaynaklar (Dergiler, Kitaplar, vb.) & 21 \\
\hline Dokuman Sayısı & 319 \\
\hline Ylllar İçinde Makale Değișimi & 5.59 \\
\hline Dokuman Bașına Atıf Sayısı & 24.28 \\
\hline Doküman başına yıllık ortalama alıntı sayısı & 3.883 \\
\hline Referanslar & 17464 \\
\hline \multicolumn{2}{|c|}{ Dokuman Türleri } \\
\hline Makale & 311 \\
\hline Editör Dokumanı & 1 \\
\hline Derleme & 7 \\
\hline \multicolumn{2}{|c|}{ Dokuman İçeriği } \\
\hline Anahtar Kelimeler - Keywords Plus (ID)* & 2280 \\
\hline Araștırmacı Anahtar Kelimesi - Author's Keywords (DE) & 1293 \\
\hline \multicolumn{2}{|c|}{ Araştırmacı } \\
\hline Araştırmacı & 742 \\
\hline Yazar Görünümleri & 903 \\
\hline Tek Yazarlı Dokuman Sayısı & 31 \\
\hline Çok Yazarlı Dokuman Sayısı & 711 \\
\hline Belge Bașına Araștırmacı Sayısı & 2.33 \\
\hline Belge Başına Ortak Yazarlar & 2.83 \\
\hline
\end{tabular}

Q1 dergilerde yıllara göre üretilen Türkiye adresli doküman sayıları; 2021 (f:44), 2020 (f:25), 2019 (f:24), 2018 (f:14), 2017 (f:22), 2016 (f:21), 2015 (f:15), 2014 (f:32), 2013 (f:25), 2012 (f:34), 2011 (f:39), 2010 (f:24), şeklindedir. İlgili yıllar içinde alınan atıf sayıları ise 2021 (f:1.519), 2020 (f:1.498), 2019 (f:1.113), 2018 (f:900), 2017 (f:740), 2016 $(f: 617), 2015$ (f:448), $2014 \quad(f: 365), 2013$ (f:268), 2012 (f:182), 2011 (f:54), 2010 (f:17) şeklindedir. Yıllara göre üretilen dokuman sayılarında büyük değişiklikler olmasa da alanda üretilen makalelerin aldığı atıflarda artışlar gözlenmiștir. Bu durum kümülatif olarak eserlerin artması ile ilişkilendirilebilir. Ortaya çıkan tablo değerlendirildiğinde, 20102021 yılları arasında Q1 dergiler gibi uluslararası YBS tartışmalarının döndüğü dergilerde Türkiye'den araştırmaların 26,58 
yayın ortalamasına sahip olması çok uygun bir tablo olarak görülmemektedir.

\subsubsection{SCImago Q1 Dergilerinde Türkiye Adresli Çalışmalar}

Tablo 6 üzerinde Q1 dergilerde Türkiye adresli araştırmalara en fazla katkı sunan araştırmacılar sunulmaktadır. İlgili araștırmacıların büyük bir bölümünün lisans, yüksek lisans veya doktora hayatları sürecinde bir șekilde yurtdıșına çıktıkları eğitim aldıkları veya kariyerlerine yurtdışında sürdürdükleri görülebilir. Asında Türkiye'deki YBS disiplinin uluslararası kabul görmesi, daha nitelikli araștırmacı ve o araștırmacıların yetiștirdiği dünyanın her yerinde YBS disiplini içinde istihdam edilebilecek nitelikte mezunlara sahip olunabilmesi için, yurt dişı eğitimin veya yurt dışı çalışma tecrübesinin çok önemli olduğu, Tablo 6'nın en önemli çıktısı olarak görülebilir. Unutulmaması gereken bir bașka nokta da, Prof. Dr. Dursun Delen ve Prof. Dr. Tuğrul Daim (TRAIS, 2021) örneklerinde olduğu gibi ulusal YBS disiplinin uluslararasılaşması, daha fazla araştırmacının Türk akademisyen diasporasının katalize etkisi ile yurt dışında daha çok kabul görmesine, bağlantı kurmasına imkan verebileceği ifade edilebilir.

Tablo 6: Q1 Dergilerde Türkiye Adresli Araștırmalara En Fazla Katkı Sunan Araștırmacılar

\begin{tabular}{|c|c|c|c|c|}
\hline Sira & Araștırmacılar & Dokuman Sayısı & Atıf Sayısı & Kurumu \\
\hline 1 & Delen D. & 13 & 365 & İbn Haldun Üniversitesi \\
\hline 2 & Kahraman C. & 8 & 471 & İstanbul Teknik Üniversitesi \\
\hline 3 & Zaim S. & 8 & 331 & İstanbul Sabahattin Zaim Üniversitesi \\
\hline 4 & Karatepe O.M. & 7 & 275 & Doğu Akdeniz Üniversitesi \\
\hline 5 & Tatoglu E. & 6 & 162 & Kuveyt Körfez Bilim ve Teknoloji Üniversitesi \\
\hline 6 & Baykasoğlu A. & 5 & 69 & Dokuz Eylül Üniversitesi \\
\hline 7 & Alhajj R. & 4 & 72 & Syddansk Üniversitesi \\
\hline 8 & Azizoğlu M. & 4 & 43 & Orta Doğu Teknik Üniversitesi \\
\hline 9 & Gunal M.M. & 4 & 40 & Milli Savunma Üniversitesi \\
\hline 10 & Köksalan M. & 4 & 117 & Orta Doğu Teknik Üniversitesi \\
\hline 11 & Okumus F. & 4 & 57 & WSB Üniversitesi \\
\hline 12 & Polat H. & 4 & 68 & Anadolu Üniversitesi \\
\hline 13 & Acharya U.R. & 3 & 26 & Ngee Ann Polyteknik Üniversitesi \\
\hline 14 & Akgün A.E. & 3 & 52 & Yıldız teknik Üniversitesi \\
\hline 15 & Altnel I.K. & 3 & 39 & Boğaziçi Üniversitesi \\
\hline 16 & Aras N. & 3 & 32 & Boğaziçi Üniversitesi \\
\hline 17 & Bayraktar E. & 3 & 124 & Orta Doğu Amerikan Üniversitesi \\
\hline 18 & Gundes S. & 3 & 49 & Mimar Sinan Güzel Sanatlar Üniversitesi \\
\hline 19 & Kaleli C. & 3 & 95 & Eskişehir Teknik Üniversitesi \\
\hline 20 & Kazancoglu Y. & 3 & 45 & Yaşar Üniversitesi \\
\hline 21 & Koç, E. & 3 & 62 & Bahçeșehir Üniversitesi \\
\hline 22 & Kozak, M. & 3 & 59 & Dokuz Eylül Üniversitesi \\
\hline 23 & Kula, U. & 3 & 27 & Orta Doğu Amerikan Üniversitesi \\
\hline 24 & Kulluk, S. & 3 & 48 & Erciyes Üniversitesi \\
\hline 25 & Köseoglu, M.A. & 3 & 40 & Metropolitan State \\
\hline 26 & Oztekin, A. & 3 & 155 & Massachusetts Lowell Üniversitesi \\
\hline 27 & Turkyilmaz, A. & 3 & 172 & Nazarbayev Üniversitesi \\
\hline 28 & Yaman, $\mathrm{H}$. & 3 & 58 & Ku Leuven \\
\hline
\end{tabular}

Lotka yasası, yazıları ile belli bir literatüre katkıları bulunan yazarların, söz-konusu katkıyı kaç yazı ile sağladıklarını belirleme olanağını sunmaktadır, şeklinde tanımlanmaktadır (Yılmaz, 2006:62). İlgili yasa, bir alanda yazı yazan yazarların literatüre olan katkılarının ne olduğunu ve bu yazarlar tarafından yazılmış yazıların o alana ait literatürde niceliksel olarak nasıl bir dağılım gösterdiğini belirlemeye çalışarak bilimsel verimlilik sürecini tahmin etmeyi amaçlamaktadır. Araştırmacıların üretmiş oldukları 319 eser için Lotka yasası çerçevesinde bir değerlendirme yapıldığında; araştırmacıların üretkenlik durumuna göre sadece 1 eserde ismi geçen araştırmacı sayısı 643, sadece 2 eserde ismi geçen araştırmacı sayısı 70, sadece 3 eserde ismi geçen 
araştırmacı sayısı 18, sadece 4 eserde ismi geçen araştırmacı sayısı 6 , sadece 6 eserde ismi geçen araştırmacı sayısı 1, sadece 7 eserde ismi geçen araştırmacı sayısı 1, sadece 8 eserde ismi geçen araștırmacı sayısı 2 ve sadece 13 eserde ismi geçen araştırmacı sayısı 13 şeklinde bir tablo ile karşılaşılmaktadır.

Tablo 7: 2010-2021 Yılları Arasında En Yoğun Atıf Alan İlk 20 Türkiye Adresli YBS Çalıșmaları

\begin{tabular}{|c|c|c|}
\hline Sira & Künye & $\begin{array}{c}\text { Atıf } \\
\text { Sayısı }\end{array}$ \\
\hline 1 & $\begin{array}{l}\text { Uğuz, H. (2011). A two-stage feature selection method for text categorization by using information gain, principal } \\
\text { component analysis and genetic algorithm. Knowledge-Based Systems, 24(7), 1024-1032. }\end{array}$ & 340 \\
\hline 2 & $\begin{array}{l}\text { Kahraman, C., Öztayși, B., Sarı, İ. U., \& Turanoğlu, E. (2014). Fuzzy analytic hierarchy process with interval type-2 } \\
\text { fuzzy sets. Knowledge-Based Systems, 59, 48-57. }\end{array}$ & 223 \\
\hline 3 & $\begin{array}{l}\text { Uysal, A. K., \& Gunal, S. (2012). A novel probabilistic feature selection method for text classification. Knowledge- } \\
\text { Based Systems, 36, 226-235. }\end{array}$ & 213 \\
\hline 4 & $\begin{array}{l}\text { Uzunoğlu, E., \& Kip, S. M. (2014). Brand communication through digital influencers: Leveraging blogger } \\
\text { engagement. International journal of information management, 34(5), 592-602. }\end{array}$ & 156 \\
\hline 5 & $\begin{array}{l}\text { Varnali, K., \& Toker, A. (2010). Mobile marketing research: The-state-of-the-art. International journal of } \\
\text { information management, 30(2), 144-151. }\end{array}$ & 149 \\
\hline 6 & $\begin{array}{l}\text { Hancer, E., Xue, B., \& Zhang, M. (2018). Differential evolution for filter feature selection based on information } \\
\text { theory and feature ranking. Knowledge-Based Systems, } 140,103-119 .\end{array}$ & 140 \\
\hline 7 & $\begin{array}{l}\text { Celik, E., Gul, M., Aydin, N., Gumus, A. T., \& Guneri, A. F. (2015). A comprehensive review of multi criteria decision } \\
\text { making approaches based on interval type-2 fuzzy sets. Knowledge-Based Systems, 85, 329-341. }\end{array}$ & 122 \\
\hline 8 & $\begin{array}{l}\text { Oztaysi, B. (2014). A decision model for information technology selection using AHP integrated TOPSIS-Grey: The } \\
\text { case of content management systems. Knowledge-Based Systems, 70, 44-54. }\end{array}$ & 117 \\
\hline 9 & $\begin{array}{l}\text { Otay, İ., Oztaysi, B., Onar, S. C., \& Kahraman, C. (2017). Multi-expert performance evaluation of healthcare } \\
\text { institutions using an integrated intuitionistic fuzzy AHP\&DEA methodology. Knowledge-Based Systems, 133, 90- } \\
106 .\end{array}$ & 94 \\
\hline 10 & $\begin{array}{l}\text { Gao, K. Z., Suganthan, P. N., Pan, Q. K., Tasgetiren, M. F., \& Sadollah, A. (2016). Artificial bee colony algorithm for } \\
\text { scheduling and rescheduling fuzzy flexible job shop problem with new job insertion. Knowledge-based systems, } \\
\text { 109, 1-16. }\end{array}$ & 85 \\
\hline 11 & $\begin{array}{l}\text { Karkin, N., \& Janssen, M. (2014). Evaluating websites from a public value perspective: A review of Turkish local } \\
\text { government websites. International journal of information management, 34(3), 351-363. }\end{array}$ & 84 \\
\hline 12 & $\begin{array}{l}\text { Karatepe, O. M. (2011). Procedural justice, work engagement, and job outcomes: Evidence from Nigeria. Journal } \\
\text { of Hospitality Marketing \& Management, 20(8), 855-878. }\end{array}$ & 82 \\
\hline 13 & $\begin{array}{l}\text { Cebi, S., \& Kahraman, C. (2010). Developing a group decision support system based on fuzzy information axiom. } \\
\text { Knowledge-Based Systems, 23(1), 3-16. }\end{array}$ & 80 \\
\hline 14 & $\begin{array}{l}\text { Tuncer, T., Dogan, S., Pławiak, P., \& Acharya, U. R. (2019). Automated arrhythmia detection using novel } \\
\text { hexadecimal local pattern and multilevel wavelet transform with ECG signals. Knowledge-Based Systems, 186, } \\
\text { 104923. }\end{array}$ & 77 \\
\hline 15 & $\begin{array}{l}\text { Karatepe, O. M., \& Ngeche, R. N. (2012). Does job embeddedness mediate the effect of work engagement on job } \\
\text { outcomes? A study of hotel employees in Cameroon. Journal of Hospitality Marketing \& Management, 21(4), } \\
\text { 440-461. }\end{array}$ & 76 \\
\hline 16 & $\begin{array}{l}\text { Yolcu, U., Egrioglu, E., \& Aladag, C. H. (2013). A new linear \& nonlinear artificial neural network model for time } \\
\text { series forecasting. Decision support systems, 54(3), 1340-1347. }\end{array}$ & 75 \\
\hline 17 & $\begin{array}{l}\text { Görmez, N., Köksalan, M., \& Salman, F. S. (2011). Locating disaster response facilities in Istanbul. Journal of the } \\
\text { Operational Research Society, 62(7), 1239-1252. }\end{array}$ & 74 \\
\hline 18 & $\begin{array}{l}\text { Turkyilmaz, A., Akman, G., Ozkan, C., \& Pastuszak, Z. (2011). Empirical study of public sector employee loyalty and } \\
\text { satisfaction. Industrial Management \& Data Systems, 111(5), 675-696 }\end{array}$ & 73 \\
\hline 19 & $\begin{array}{l}\text { Kıran, M. S., Özceylan, E., Gündüz, M., \& Paksoy, T. (2012). Swarm intelligence approaches to estimate electricity } \\
\text { energy demand in Turkey. Knowledge-Based Systems, 36, 93-103. }\end{array}$ & 71 \\
\hline 20 & $\begin{array}{l}\text { Barlas, Y., \& Gunduz, B. (2011). Demand forecasting and sharing strategies to reduce fluctuations and the bullwhip } \\
\text { effect in supply chains. Journal of the Operational Research Society, 62(3), 458-473. }\end{array}$ & 71 \\
\hline
\end{tabular}

Ayrıca, Tablo 7 üzerinde Türkiye adresli en yoğun atıf alan ilk 20 eser paylaşılmaktadır. Araştırmacıların 11 eser ile Knowledge-Based Systems dergisinde, üç eser ile International Journal of Information Management dergisi, iki eser ile Journal of Hospitality Marketing \&
Management ve Journal of the Operational Research Society dergileri, bir çalışma ile Industrial Management \& Data Systems dergisinde yayın yaptıkları Tablo 7'de görülmektedir. Yine aynı tabloda görüleceği üzere belirtilen kapsamda Knowledge-Based 
Systems dergisi en çok yayın yapılan dergi olarak ifade edilebilir.

\subsubsection{Dergilerin Değerlendirilmesi}

2010-2021 yılları Q1 dergilerde Türkiye adresli araştırmaların dağılımı Tablo 8 üzerinde gösterilmektedir. Türkiye adresli bilgisayar bilimleri, yapay zeka konularında önemli bir etki değerine sahip (2020 etki değeri, 8,038 puan) Knowledge-Based Systems dergisi 90 dokumana sahiptir. Ardından ilk beş içinde yer alan diğer dergiler sırasıyla; Journal of The Operational Research Society (f:74), Journal of Hospitality Marketing and Management (f:40), Decision Support System (f:30), International Journal of Information Management $(f: 18)$ şeklindedir. Yönetim; yöneylem araştırmaları ve yönetim bilimi alanında alanın önemli dergilerinden birisi olan Journal of The Operational Research Society dergisinde de araştırmacıların katkı sunduğu görülmektedir.

Tablo 8: 2010-2021 Yılları Arasında Q1 Dergilerde Türkiye Adresli Araștırmaların Dağılımı

\begin{tabular}{|c|c|c|c|c|}
\hline \# & Dergi & $\begin{array}{c}\text { Dokuman } \\
\text { Sayısı }\end{array}$ & $\begin{array}{l}2020 \text { Yılı Etki } \\
\text { Değeri }\end{array}$ & Odaklanılan Araștırma Alanları \\
\hline 1 & Knowledge-Based Systems & 90 & 8,038 & Bilgisayar Bilimleri, Yapay Zeka \\
\hline 2 & Journal of The Operational Research Society & 74 & 2,86 & $\begin{array}{l}\text { Yönetim; Yöneylem Araştırmaları ve Yönetim } \\
\text { Bilimi }\end{array}$ \\
\hline 3 & Journal of Hospitality Marketing And Management & 40 & 7,022 & $\begin{array}{l}\text { İssletme; Otelcilik, Eğlence, Spor \& Turizm; } \\
\text { Yönetim }\end{array}$ \\
\hline 4 & Decision Support Systems & 30 & 5,795 & 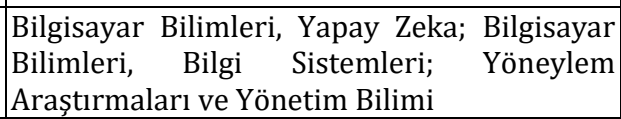 \\
\hline 5 & International Journal of Information Management & 18 & 14,098 & Bilgi Bilimi \& Kütüphane Bilimi \\
\hline 6 & Industrial Management and Data Systems & 11 & 4,224 & $\begin{array}{|lcc|}\text { Bilgisayar } \quad \text { Bilimleri, } & \text { Disiplinlerarasi } \\
\text { Uygulamalar; } & \text { Mühendislik, Endüstriyel }\end{array}$ \\
\hline 7 & $\begin{array}{l}\text { International Journal of Logistics Research And } \\
\text { Applications }\end{array}$ & 10 & 3,821 & Yönetim \\
\hline 8 & Construction Management and Economics & 8 & - & İşletme ve Ekonomi \\
\hline 9 & Computational Management Science & 7 & - & Sosyal Bilimlerde Matematiksel Yöntemler \\
\hline 10 & $\begin{array}{l}\text { Journal of Humanitarian Logistics and Supply Chain } \\
\text { Management }\end{array}$ & 7 & - & İşletme ve Ekonomi \\
\hline 11 & Information and Management & 4 & 7,555 & $\begin{array}{l}\text { Bilgisayar Bilimleri, Bilgi Sistemleri; Bilgi } \\
\text { Bilimi \& Kütüphane Bilimi; Yönetim }\end{array}$ \\
\hline 12 & Information Society & 3 & 4,571 & İletişim; Bilgi Bilimi \& Kütüphane Bilimi \\
\hline 13 & $\begin{array}{l}\text { International Entrepreneurship and Management } \\
\text { Journal }\end{array}$ & 3 & 5,94 & İşletme; Yönetim \\
\hline 14 & $\begin{array}{l}\text { International Journal of Systems Science: } \\
\text { Operations and Logistics }\end{array}$ & 3 & - & $\begin{array}{l}\text { Mühendislik; Yöneylem Araştırması ve } \\
\text { Yönetim Bilimi }\end{array}$ \\
\hline 15 & European Journal of Information Systems & 2 & 4,344 & $\begin{array}{l}\text { Bilgisayar Bilimleri, Bilgi Sistemleri; Bilgi } \\
\text { Bilimi \& Kütüphane Bilimi; Yönetim }\end{array}$ \\
\hline 16 & Information Systems Research & 2 & 5,207 & Bilgi Bilimi \& Kütüphane Bilimi; Yönetim \\
\hline 17 & Journal of Contingencies and Crisis Management & 2 & 4,391 & Yönetim \\
\hline 18 & Journal of Management Information Systems & 2 & 7,838 & \begin{tabular}{|l} 
Bilgisayar Bilimleri, Bilgi Sistemleri; Bilgi \\
Bilimi \& Kütüphane Bilimi; Yönetim
\end{tabular} \\
\hline 19 & Data Base for Advances in Information Systems & 1 & 1,828 & Bilgi Bilimi \& Kütüphane Bilimi \\
\hline 20 & Journal of Supply Chain Management & 1 & 8,647 & Yönetim \\
\hline 21 & MIS Quarterly: Management Information Systems & 1 & 7,198 & $\begin{array}{l}\text { Bilgisayar Bilimleri, Bilgi Sistemleri; Bilgi } \\
\text { Bilimi \& Kütüphane Bilimi; Yönetim }\end{array}$ \\
\hline
\end{tabular}

Tablo 8'i incelediğinizde üçüncü sırada yer alan Journal of Hospitality Marketing and Management dergisinin her ne kadar YBS dergileri içinde konumlansa ve Q1 listesi içinde yer alsa da diğer dergiler gibi bilgisayar bilimlerinden ziyade alana daha çok yönetim ve işletme boyutuyla yakınsadığı görülebilir. Tüm bunlara ek olarak alanda 2020 yılında her ne kadar Scopus tarafından taransa da SCI, SSCI, ESCI veya SCI-Expanded indekslerinde yer almayan dergilerin olduğu da ifade edilebilir. Bu durum Türkiye doçentlik kriterlerinde ilgili indekslerin referans alınması nedeniyle, alanda çalışan araştırmacıların ilgisini çekebileceği 
düşüncesiyle, özellikle paylaşılmıştır. İlgili alanda daha kapsamlı araştırma yapmak ve Web of Science verileri ile çalışmak isteyen araştırmacıların çalışmalarını daha sağlıklı yürütebilmeleri için 2020 etki değeri olan dergilere odaklanmalarında fayda vardır.

Ayrıca Şekil 2 üzerinde yer alan ülkelere göre Scopus veri tabanında yer alan dergiler arasında Türkiye'den sadece bir derginin (International Journal of eBusiness and eGovernment Studies) yer alması, alanda son yıllarda hızla açılan lisans, yüksek lisans ve doktora eğitimi ve istihdam edilen araştırmacı sayısı dikkate alındığında (YÖK Akademik, 2021; YÖK İstatistik) düşündürücüdür. Karaman ve diğerleri (2020), Türkiye adresli uluslararası hukuk çalışmalarını değerlendirdikleri çalışmalarında, uluslararası yayın faaliyetlerinin Türkiye'deki hukuk alanının gelişmesine ve uluslararasılaşmasına etkisi olacağını ifade etmiştir. $\mathrm{Bu}$ durumun Türkiye'deki YBS disiplinin daha fazla uluslararasılaşması için de geçerli olduğu ifade edilebilir.

\subsubsection{Kurum ve Ortak Çalışılan Ülkeler}

Türkiye'deki kurumların 2010-2021 yılları arasında Q1 dergilerdeki yayın üretkenlikleri Tablo 9 üzerinde verilmiştir. Elde edilen tabloda ilk bește yer alan kurumlar sırasıyla; Orta Doğu Teknik Üniversitesi (f:39), İstanbul Teknik Üniversitesi (f:38), Erciyes Üniversitesi (f:18), Anadolu Üniversitesi (f:16), Bilkent Üniversitesi $(f: 15)$ șeklindedir. Ortaya konulan tabloda her ne kadar Türkiye adresli araştırmaları incelesek de yurt dışındaki Oklahoma Devlet Üniversitesi $(f: 14)$, Bath Üniversitesi $(f: 14), \quad$ Amirkabir Teknoloji Üniversitesi (f:7), Alto Üniversitesi $(f: 5)$, Singapur Ulusal Üniversitesi (f:5), Hong Kong Politeknik Üniversitesi ( $f: 5)$, Merkez Florida Üniversitesi $(f: 5)$ gibi üniversitelerdeki araştırmacıların Türkiye adresli YBS araştırmalarına katkı sunduğu görülmektedir.

Tablo 9: 2010-2021 Yılları Q1 Dergilerde Türkiye Adresli Araştırmaların Kurumlara Göre Dağılımı (Minimum 5 Dokuman)

\begin{tabular}{|c|c|c|c|c|c|}
\hline Sira & Kurum & $\begin{array}{r}\text { Dokuman } \\
\text { Sayısı } \\
\end{array}$ & Sira & Kurum & $\begin{array}{r}\text { Dokuman } \\
\text { Sayısı } \\
\end{array}$ \\
\hline 1 & Orta Doğu Teknik Üniversitesi & 39 & 25 & Yaşar Üniversitesi & 7 \\
\hline 2 & İstanbul Teknik Üniversitesi & 38 & 26 & Ankara Üniversitesi & 6 \\
\hline 3 & Erciyes Üniversitesi & 18 & 27 & Boğaziçi Üniversitesi & 6 \\
\hline 4 & Anadolu Üniversitesi & 16 & 28 & Çankaya Üniversitesi & 6 \\
\hline 5 & Bilkent Üniversitesi & 15 & 29 & Dokuz Eylül Üniversitesi & 6 \\
\hline 6 & Boğaziçi Üniversitesi & 14 & 30 & Galatasaray Üniversitesi & 6 \\
\hline 7 & Oklahoma Devlet Üniversitesi & 14 & 31 & İbn Haldun Üniversitesi & 6 \\
\hline 8 & Calgary Üniversitesi & 13 & 32 & İzmir Ekonomi Üniversitesi & 6 \\
\hline 9 & Doğu Akdeniz Üniversitesi & 12 & 33 & Koç Üniversitesi & 6 \\
\hline 10 & Fatih Üniversitesi & 12 & 34 & Sakarya Üniversitesi & 6 \\
\hline 11 & Sabancı Üniversitesi & 11 & 35 & $\begin{array}{lll}\text { TOBB Ekonomi } & \text { ve } & \text { Teknoloji } \\
\text { Üniversitesi } & & \\
\end{array}$ & 6 \\
\hline 12 & Özyeğin Üniversitesi & 10 & 36 & Alto Üniversitesi & 5 \\
\hline 13 & Yıldız Teknik Üniversitesi & 10 & 37 & $\begin{array}{lccc}\text { Akdeniz Üniversitesi } & \text { Turizm } & \text { ve } \\
\text { Otelcilik Yüksekokulu } & & \\
\end{array}$ & 5 \\
\hline 14 & Boğaziçi Üniversitesi & 9 & 38 & Ege Üniversitesi & 5 \\
\hline 15 & Fırat Üniversitesi & 9 & 39 & Gebze Teknik Üniversitesi & 5 \\
\hline 16 & Marmara Üniversitesi & 9 & 40 & İstanbul Aydın Üniversitesi & 5 \\
\hline 17 & Dokuz Eylül Üniversitesi & 8 & 41 & İstanbul Üniversitesi & 5 \\
\hline 18 & Gazi Üniversitesi & 8 & 42 & Kadir Has Üniversitesi & 5 \\
\hline 19 & Selçuk Üniversitesi & 8 & 43 & Karadeniz Teknik Üniversitesi & 5 \\
\hline 20 & Uludağ Üniversitesi & 8 & 44 & MEF Üniversitesi & 5 \\
\hline 21 & Bath Üniversitesi & 8 & 45 & Singapur Ulusal Üniversitesi & 5 \\
\hline 22 & Amirkabir Teknoloji Üniversitesi & 7 & 46 & Hong Kong Politeknik Üniversitesi & 5 \\
\hline 23 & Gebze Teknoloji Enstitüsü & 7 & 47 & Merkez Florida Üniversitesi & 5 \\
\hline 24 & Hacettepe Üniversitesi & 7 & & & \\
\hline
\end{tabular}


Şekil 4 üzerinde yurtdışındaki üniversitelerin etrafında kümelenen farklı üniversitelerin olduğu görülmektedir. Örneğin Oklahoma Devlet Üniversitesi ile İstanbul Teknik Üniversitesi, İbn Haldun Üniversitesi, Fatih Üniversitesi, Marmara Üniversitesi ve Bahçeşehir Üniversitesi'nin birlikte çalıştığ Singapur Ulusal Üniversitesi ile İzmir Ekonomi Üniversitesi'nin, Florida Merkez Üniversitesi ile Hong Kong Politeknik Üniversitesi'nden araştırmacıların birlikte çalıştığı görülebilir. $\mathrm{Bu}$ durum YBS alanında olușturulabilecek Türk araştırmacı diasporasının da alana önemli bir etkisi olabileceğini göstermektedir. Ayrıca, Türkiye'deki uluslararasılaşma için de reçete olabilecek bir strateji olduğu da gözden kaçırılmamalıdır. Alanında uzman ve kendini uluslararası bilimsel yetkinlikte geliştirmiş araștırmacıların yurtdışında bulunması ve buralardaki araştırma merkezlerinde, üniversitelerde görev yapması, Türkiye'deki aynı alanların gelişmesi için de önemli bir etkiye sahip olduğu ortadadır.

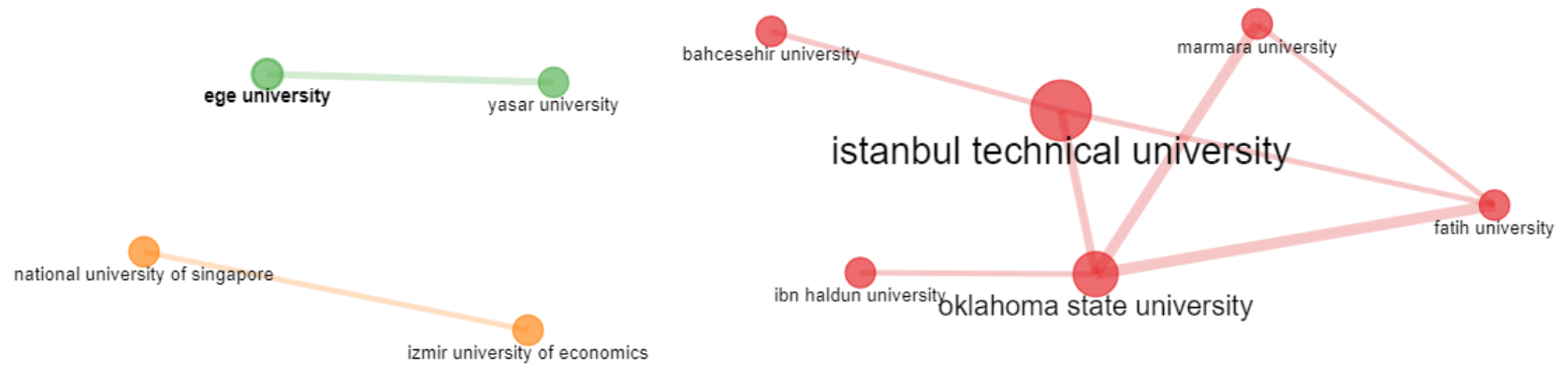

middle east technical university

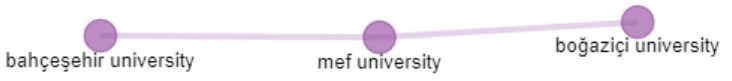

Şekil 4: Kurumların Birlikte Çalışma ve Ortak İşbirliği Durumu

Tablo 10: Türkiye Adresli Çalışmalarda Ortak Çalışılan Ülkeler ve En Yoğun Birlikte Çalışılan Kurum (Minimum 3)

\begin{tabular}{|l|l|c|l|}
\hline Sıra & Ülke & Dokuman Sayısı & En Fazla Birlikte Çalışılan Kurum \\
\hline 0 & Türkiye & 619 & - \\
\hline 1 & Amerika Birleşik Devletleri & 64 & Oklahoma Devlet Üniversitesi \\
\hline 2 & Birleşik Krallı & 23 & Bath Üniversitesi, Sheffield Üniversitesi \\
\hline 3 & Kanada & 14 & Calgary Üniversitesi \\
\hline 4 & Singapur & 9 & Ngee Ann Politeknik \\
\hline 5 & Hindistan & 7 & Malaviya Ulusal Teknoloji Enstitüsü Jaipur \\
\hline 6 & İran & 7 & Amirkabir Teknoloji Üniversitesi \\
\hline 7 & Kuveyt & 7 & Orta Doğu Amerikan Üniversitesi \\
\hline 8 & Hollanda & 7 & Delft Teknoloji Üniversitesi \\
\hline 9 & Polonya & 6 & Poznan Teknoloji Üniversitesi \\
\hline 10 & Hong Kong & 5 & Hong Kong Politenik Üniversitesi \\
\hline 11 & Avustralya & 4 & RMIT Üniversitesi \\
\hline 12 & Tayvan & 4 & Asya Üniversitesi \\
\hline 13 & Fransa & 3 & Avrupa RFID Performans Test Merkezi, EDC Paris İşletme Okulu \\
\hline 14 & Almanya & 3 & Zeplin Üniversitesi \\
\hline 15 & İtalya & 3 & Free University of Bozen-Bolzano \\
\hline 16 & İspanya & 3 & Oberta de Catalunya Üniversitesi, Autonoma de Barcelona Üniversitesi \\
\hline
\end{tabular}

Şekil 4 üzerinden elde edilebilecek bir bașka bulgu da aynı bölgede olan üniversitelerin birbirleri ile daha yoğun iş birliği yaptı̆̆ bulgusudur. Ege Üniversitesi ve Yaşar 
Üniversitesi, Orta Doğu Teknik Üniversitesi ve Çankaya Üniversitesi, Bahçeșehir Üniversitesi ile MEF Üniversitesi ve Boğaziçi Üniversitesi arasındaki işbirlikleri örnek olarak verilebilir. Ayrıca Şekil 4 üzerinde yurt dışından bazı üniversitelerin olduğu görülebilir. Tablo 10 üzerinde bilgi ve iletişim teknolojileri sektöründe önemli konumda olan ülkelerin olduğu (Amerika Birleşik Devletleri: 64, Birleşik Krallı:23, Kanada:14, Singapur:9, Hindistan:7) görülebilir. Bununla birlikte bölgesel komşumuz olan İran (f:7) ve Kuveyt (f:7) gibi ülkeler ile de YBS alanında çalışan akademisyenlerimizin işbirliğine girdiği görülebilir.

Türkiye merkezli YBS disiplininde çalıșan araştırmacılar merkeze alınarak, araştırmacılarımız daha farklı hangi ülkelerin araştırmacıları ile birlikte çalıştığı ve bu ülkelerin daha farklı hangi ülkeler ile birlikte çalıştığı Şekil 5 üzerinde gösterilmektedir. Yönetim bilişim sistemleri, Türkiye'de her geçen yll akademik kadrosu (YÖK Akademik, 2021), açılan yeni bölüm ve programları ve mezun ettiği öğrencileri (YÖK İstatistik, 2021) ile büyüyen bir alandır. Damar ve Özdağoğlu (2021:311) yazılım sektörünün gelişmekte olan ülkelere yeni firsat yaratma ve katma değer sağlama konusunda önde gelen sektörler arasında yer aldığını belirtmiş, Türkiye'deki genç ve dinamik nüfus avantajı ile bu potansiyeli yakalamak için önemli bir avantaja sahip olduğunu belirtmişlerdir. Yazılım sektörü ile doğrudan veya dolaylı ilişkisi olabilecek disiplinler konusunda, yurtdışı yüksek lisans ve doktora eğitimlerinin, uluslararası ortak araştırma projelerinin yürütülmesinin, alınan desteklere araştırmacıların teşvik edilmesi adına devlet desteğinin de verilmesinin, bu yönde nitelikli araştırmacı ve girişimci kalitesini artıracağını ifade etmişlerdir.

Heeks ve Nicholson (2002:21-22), ülkeler, yazılım ihracatı için hayati önem taşıyan uluslararası bağlantıları kurmak için ne yapabilir sorusuna dört çözüm önerisi sunmuştur. Bunlardan ilki ve en önemlisi;
"İnsanların dışarı çıkmasını kolaylaştırın" ilkesidir. Çalışmalarında bu durumu gerçekleştirilebilmesi için sırasıyla; yazılım sektöründeki yorucu bürokrasinin azaltılması gerektiğini, diğer ülkeler ile ortak çalışma yapmadaki zorlukların aşılması gereğini ve sektördeki uzman iş gücünün ve nitelikli kişilerin diğer ülkelere taşınmasındaki kısıtlamaların kaldırılması gerektiği ve hatta teşvik edilmesi gerektiğini ifade etmişlerdir.

Ayrıca sektördeki firmaların yurtdışı yatırımlarının desteklenmesi için özel stratejiler belirlenmesi gerektiği, bu ülkelerin sektörün öncü ülkeleri (ABD, Hindistan, İsrail, Çin, Brezilya, Finlandiya veya İrlanda gibi) veya rahat ve etkin satış yapabilecek (İran, Irak, Azerbaycan, Gürcistan gibi) ülkeler olmasının tercih edilebileceğini ve bu tür girişimlerin devlet politikası haline getirilmesi gerektiği ifade edilebilir (Damar ve Özdağoğlu, 2021:331). Bu noktada dönemsel olarak yayınlanan TUBİTAK Proje çağrılarında yazılım sektörünün yurtdışı pazara açllabilmesi, var olan pazarlarda yeni bağlantılar kurulmasını veya yeni pazarlara girişin sağlanması desteklenebilir ve bu yönde hem Türkiye'deki YBS disiplinin uluslararasılaşması hem de yazılım sektörü için potansiyel pek çok ülkeye ulaşarak ülke ekonomisine ve gelişimine katkıda bulunulabilir. $\mathrm{Bu}$ girişimde unutulmaması gereken en önemli noktanın yazılım sektörünün bilgi işçiliği olduğu, üzerinde çalışılan ve çözüm üretilen iş ve işin mevzuatları hakkında derin bilgi birikimine sahip olunması gerekliliğidir. Bu nedenle ilgili ülkelerde lisans, yüksek lisans, doktora eğitimi almış ve/veya bu ülkelerde ilgili veya ilişkili sektörlerde tecrübe edinmiş ve pazar konusunda, ülke bürokrasisi ve sektörün işleyişi, boşlukları ve gereksinimleri konusunda bilgi sahibi olan nitelikli araştırmacıların veya sektör çalışanlarının Türkiye'deki yazılım sektörünün yurtdışına açılması için de çok önemli bir etki yaratacağı düşünülmektedir. Ayrıca TÜBİTAK'ın çeşitli dönemlerde yurtdışına yüksek lisans, doktora veya doktora sonrası araştırmacı göndermek üzere sağladığı burslar ile yönetim bilişim 
sistemleri, yazılım mühendisliği, bilgisayar mühendisliği gibi yazılım sektörü ile ilişkilendirilebilecek programların mezunlarına pozitif ayrımcllk yapabilir veya bu tür pozitif ayrımcıllk yapabilecek program çağrıları için özel bir program numarası düzenlenerek çağrıya çıkabilir. Bu şekilde yapılacak düzenlemeler ile Türkiye'nin potansiyelinin ortaya çıarılması ve bu potansiyelden en hızlı şekilde yararlanılması konusunda katkı sunacaktır.

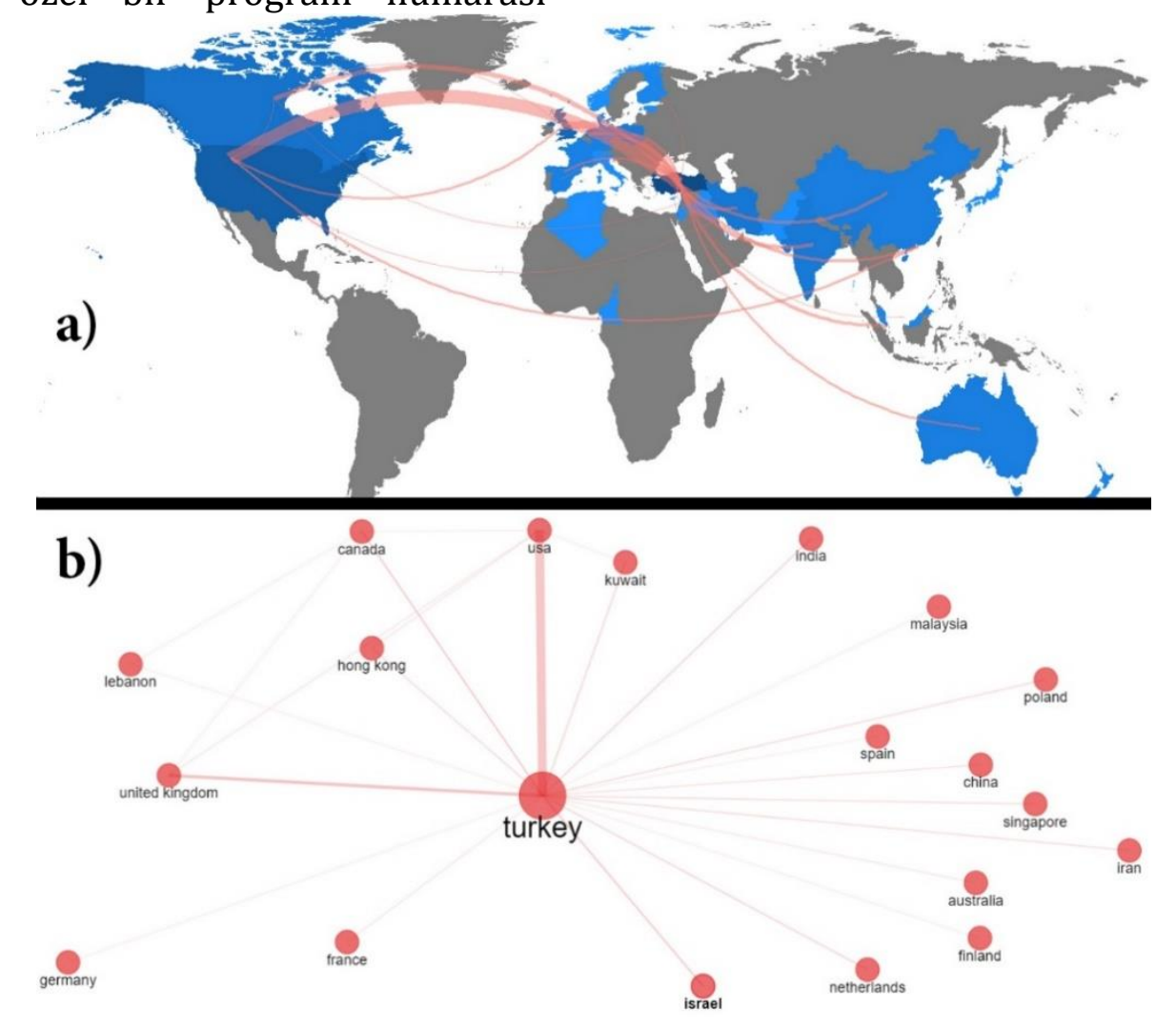

Şekil 5. Türkiye Adresli YBS Çalışmalarında Ortak Çalışılan Ülkelerin Harita Üzerinde Gösterimi

\subsection{3 İçerik Analizi}

Kefkir (2019), YBS çalışma alanının çok disiplinli yapısı nedeniyle, bu alanda bilimsel yayın üreten üniversitelerin/ekollerin sıklıkla hangi alt konulara yoğunlaştığının sosyal ağ analiziyle bir haritasının çıkarılmasının anlamlı olduğunu ifade etmiştir. Şekil 6 üzerinde bu ifadeyi destekleyen bir görünüm sunulmaktadır. Türkiye adresli Q1 dergileri üzerinde yayınlanan araştırmaların genel dokusu ve ön plana çıkan konular şekilde de görüleceği üzere çeşitli konu başlıkları etrafında yoğunlaşmaktadır. Bu görseller YBS alanındaki en önemli dergiler üzerinde Türkiye adresli araştırmacıların araştırma dokusunu ortaya koymaktadır. Şekil 7 üzerinde ise iki farklı girdi üzerinden ortak sıklık analizi yapılmıştır. Bunlardan birincisi anahtar kelimeler üzerine gerçekleștirilen ortak sıklı analizi, diğeri ise araştırmaların başlıkları üzerine gerçekleștirilen ortak sıklık analizidir. Ortak sıklık analizini (co-occurrence analysis), birlikte meydana gelme, aynı anda veya aynı yerde ortaya çıkma, sıklıkla birlikte çalışılan kelimelerin ortaya konulduğu analiz şekli olarak ifade edebiliriz. Makalelerde kullanılan başlık, özet veya anahtar kelimeler üzerine gerçekleștirilebilecek bu analiz sayesinde, belirli kelimeler, belirli diğer kelimelerle düzenli olarak birlikte ortaya çıkma durumu veya yan yana gelme durumuna göre kümelenmekte, makalelerde konuların yoğunlaştığı alan noktasında analiz sonrası bulgu elde etmemize fayda sağlamaktadır.

Şekil 6a'da anahtar kelimeler üzerine gerçekleștirilen analizde, toplamda altı küme 
elde edilmiştir. Karar destek, bulanık kümeler, sağlık hizmeti, karar teorisi, yapay zeka, karar destek sistemleri birinci kümemizi oluşturmaktadır. Yatırım, ticaret, maliyetler, ekonomi ikinci kümemizi; proje yöneticiliği, bütçe kontrolü, ekonomi ve sosyal etkiler, tamsayı programlama, doğrusal programlama, bilgisayar simülasyonlarını incelemek için kullanılan hesaplama deneyimleri, üçüncü kümemizi oluşturmaktadır. Metin işleme, özellik çıkarma, destek vektör makineleri, yapay sinir ağları, algoritmalar, öğrenen algoritmalar, karar ağaçları, derin öğrenme, hassasiyet analizleri, dördüncü kümemizi oluşturmaktadır. Kümeleme algoritmaları, genetik algoritmalar, çizelgeleme, satış, metasezgisel algoritma, hesaplama sonuçları, sezgisel yöntemler ve algoritmalar, beşinci kümemizi ve son olarak dizayn-metodolojiyaklaşım, endüstri, tedarik zinciri yönetimi, tedarik zinciri, üretim ve araştırmalar altıncı kümemizi olușturmaktadır. Elde edilen bu doku YBS alanında çalışan ve uluslararası yayınlar konusunda daha etkin olmak isteyen araştırmacılar için de aynı zamanda referans ve kllavuz bir bilgidir.
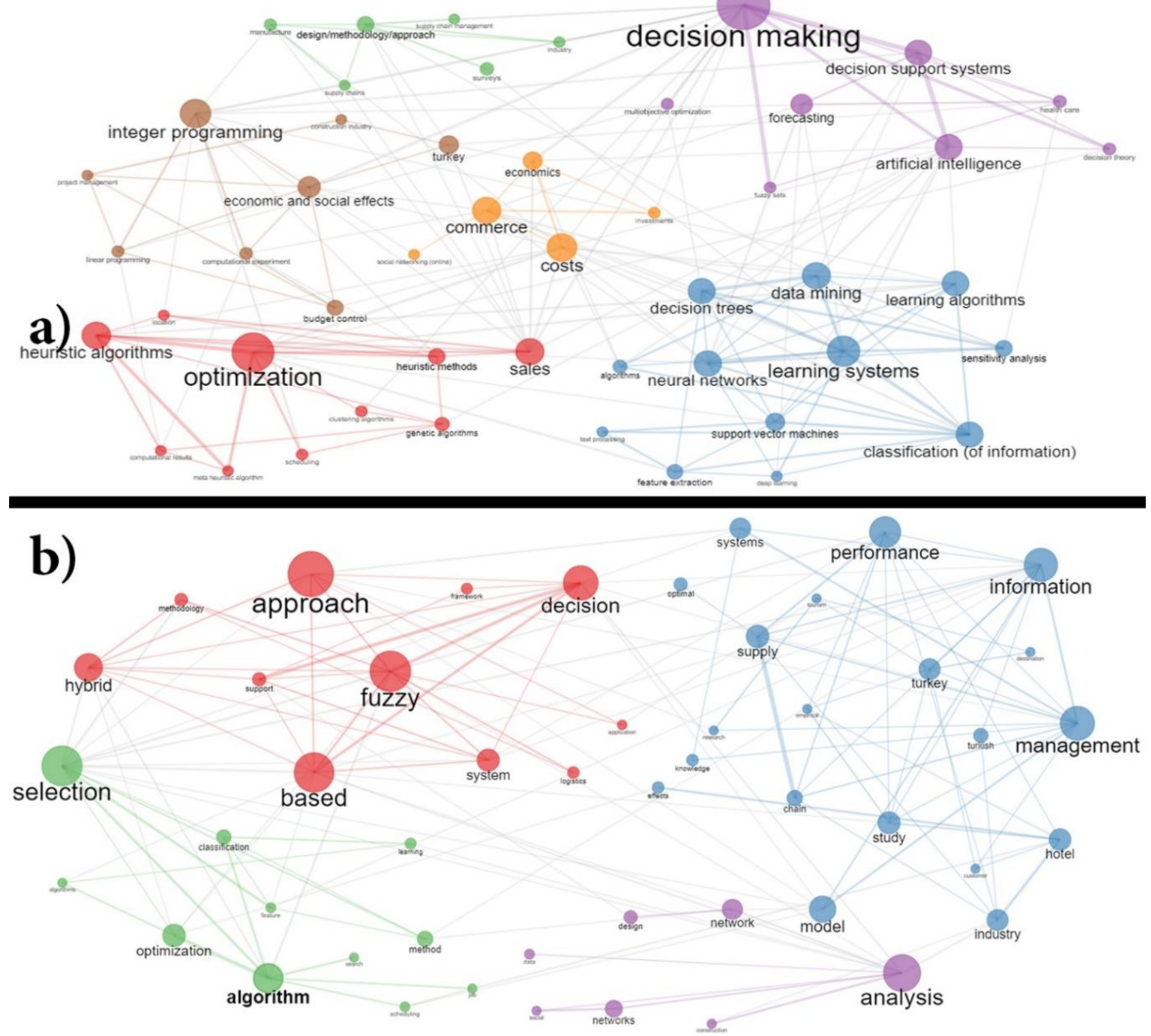

Şekil 6. Türkiye Adresli Q1 Dergilerde Üretilen ve Anahtar Kelimelerin Ortak Kullanım Analizi 


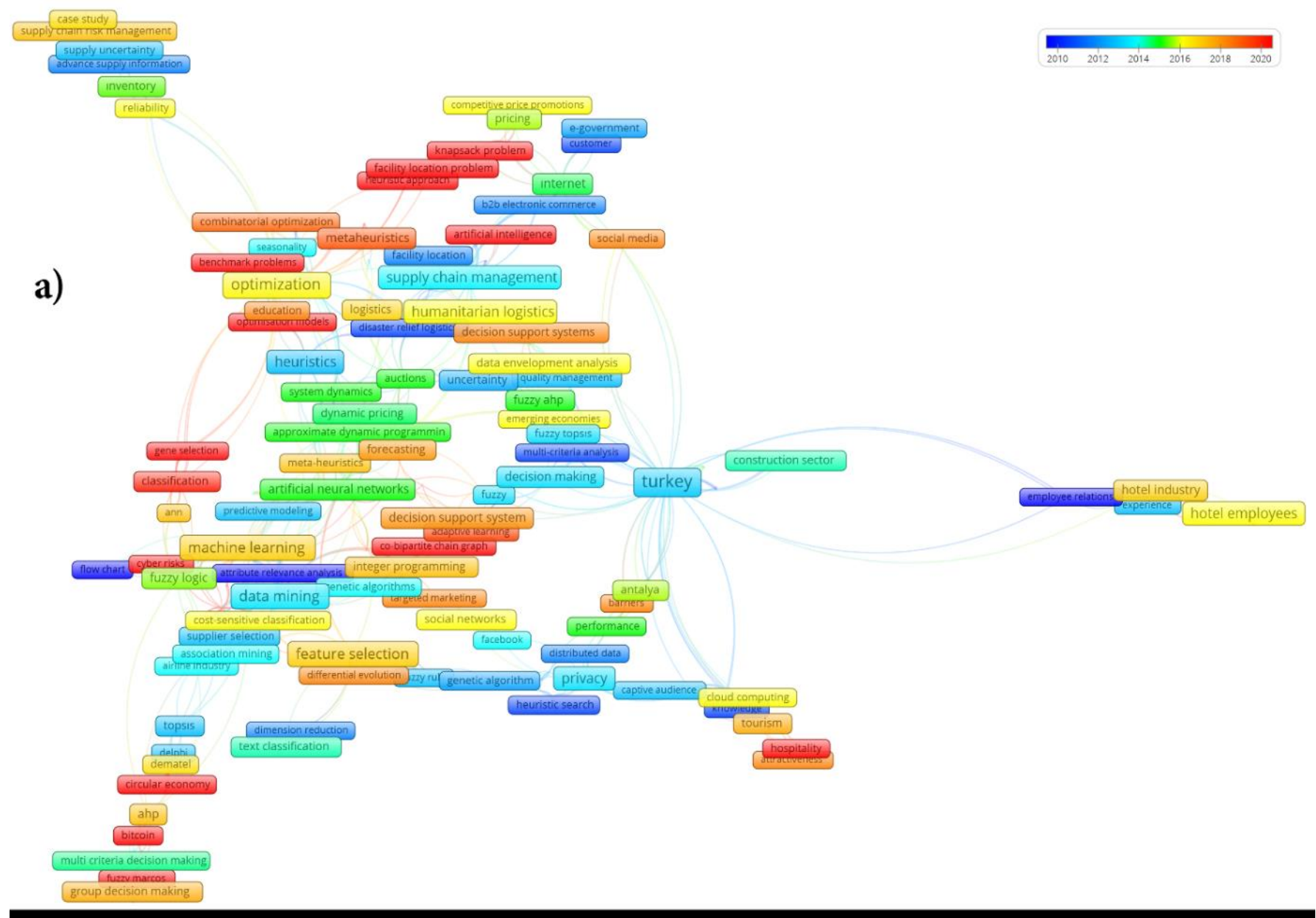

b)

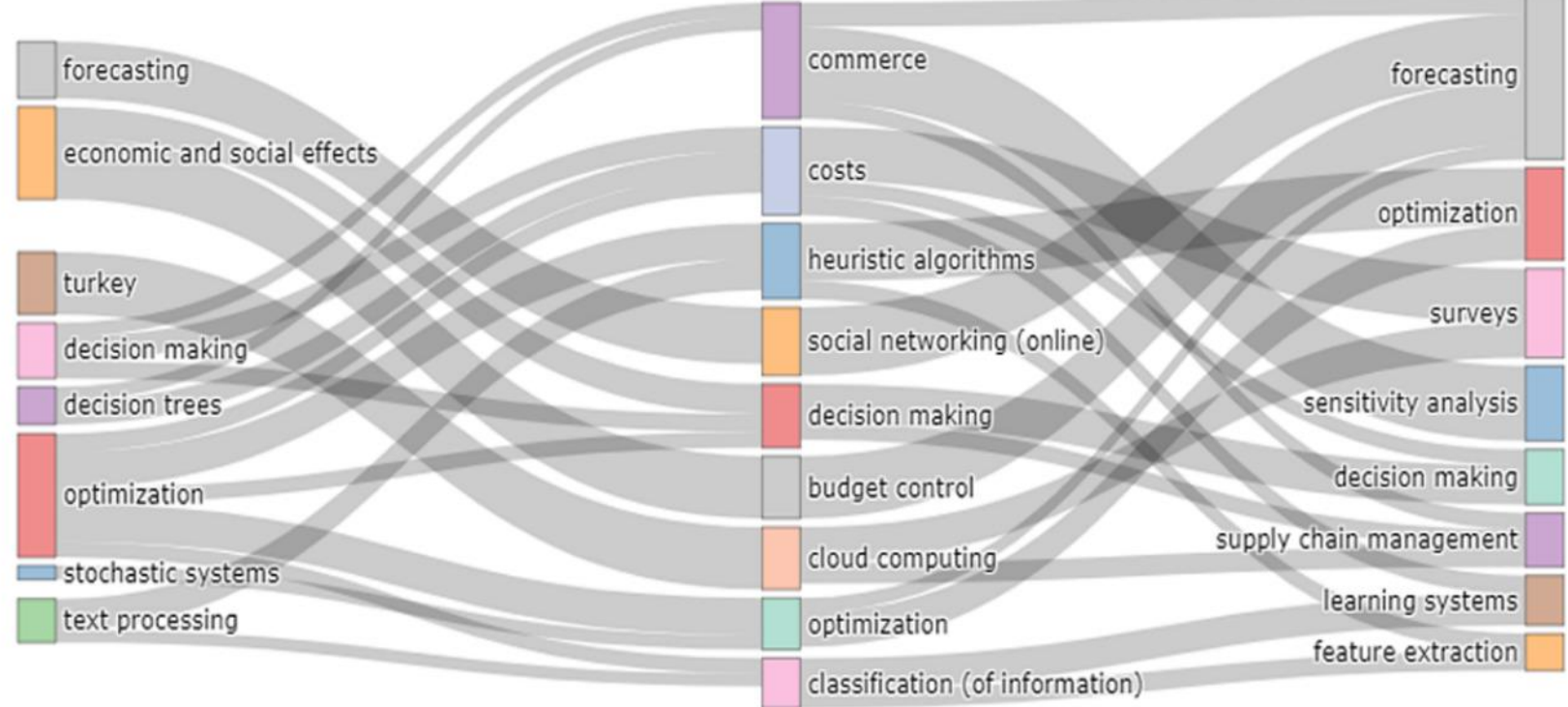

Şekil 7. Anahtar Kelimelere Göre Tematik ve Zaman Boyutu İle Değerlendirme

Şekil 6b'de görülebilen, ikinci analizimiz olan üretilen araştırma başlıkları üzerine gerçekleştirilen analizde, birinci analizimize benzer bir doku ile karşılaşılmıştır. Birinci analizden farklı olarak, bilgi yönetimi, performans, Türkiye ve Türkçe, turizm, otel, müşteri, malumat, endüstri, model, etki, en uygun, sistemler, etki, önemli gibi araştırma 
başlıkları çalıșılan bir küme olarak karşımıza çıkmaktadır. Turizm ve otel kelimelerinin ön plana çıkan dokular olarak karşımıza çıkması, Tablo 7'de görülen Journal of Hospitality Marketing and Management (f:40) turizm dergisinde Türkiye adresli araştırmacılarımızın üretken olması ile ilişkilendirilebilir. Türkiye'nin dünyada sözü geçen bir turizm ülkesi olması ve uluslararası yayın üretkenliği konusunda bu şekilde bir tablonun çıkması da olumlu bir durum olarak belirtilmekte fayda vardır.

Kullanılan anahtar kelimelerin ortak sıklık analizi ve yıllara göre dağılımı 2010-2021 yılları arasındaki dağılımı Aşağıda Şekil 7a üzerinde gösterilmektedir. Bununla birlikte kullanıcı anahtar kelimelerinin 2010-2013 dönemi, 2014-2017 dönemi ve 2018-2021 dönemlerinde kullanım durumlarını ve tematik dokusu Şekil 7b'de gösterilmektedir. Karar verme ve karar süreçleri ile ilgili konular 20102021 yılları içinde güncelliğini ve yoğun çalışılan konu olma özelliğini devam ettirmiştir. Karar süreçleri, metin işleme, optimizasyon, karar ağaçları, akış diyagramları, tedarikçi belirsizliği ve seçimi, genetik algoritmalar, TOPSIS (Technique for Order of Preference by Similarity to Ideal Solution) gibi yöntemler ve hava yolu sektörü, Facebook, tedarik zinciri yönetimi, çalışan ilişkileri, gibi konular 2010'un ilk dönemlerinde ilgili literatürde yoğun tartışılan konular olarak karşımıza çıkmaktadır.

Sosyal ağlar, rekabetçi fiyat promosyonları, güvenirlik, otel çalışanları ve otel endüstrisi, makine öğrenmesi, fiyata duyarlı kümeleme, tedarikçi seçimi risk yönetimi, lojistik, dematel yöntemi, bulut bilişim, AHP (Analitik Hiyerarşi Süreci-Analytical Hierarchy Process), bütçe kontrolü, maliyetler, online sosyal ağlar, bilginin sinıflandırılması 2014-2017 yılları arasında yoğun tartışılan konular olarak karşımıza çıkmıştır. Son yıllara gelindiğinde öğrenme sistemleri, bitcoin, döngüsel ekonomi, siber riskler ve hedef pazarlar ilgili dergilerde Türkiye adresli araştırmalarca yoğun tartışılan konular olarak karşımıza çıkmaktadır. Elde edilen bu bulgular aynı zamanda 2010 ve sonrası ulusal araştırmacıların uluslararası YBS literatüründe tartıştıkları konular hakkında bilgi vermekte, zaman bölümleri içinde ne şekilde hangi konulara odaklanarak katkı sunduklarını göstermektedir.

Yazılım endüstrisi için kaliteli ve standartlara uygun yazılım geliştirme sorunu hemen hemen tüm dünyadaki yazılım firmaları için ortak sorundur. Kalite ve standartlara uygun yazılım üretimi, yazılım sektöründe faaliyet gösteren firmalar için etkili rekabet imkanı sağlamakta, ekonomik çerçeve içinde güvenli, güvenilir ve kullanışlı yazılım ürünleri ve hizmetleri dağıtmasını sağlayacak araçlar ve teknolojiler sunmalarına imkan vermektedir (Osterweil vd., 1996:738). Bu soruna çözüm getirebilen ulusal ekonomiye, yazılım sektörünün içinde barındırdığı dinamikler dikkate alındığında, ulusal güvenlik, uluslararası rekabet edebilirlik ve toplumsal refahın artışı üzerinde önemli bir etkiye sahip olacaktır. Türkiye'de YBS alanında çalışan araştırmacılar için yazılım sektöründe kalite, bu kalitenin Türkiye ve dünya genelinde nasıl artırılabileceği, bu sayede yazılım sektöründeki küresel rekabet içinde nasıl daha iyi hale gelebileceği problemi odaklanabilecek, alanın dokusuna ve yapısına uygun bir araștırma alanıdır. Yönetim bilişim sistemleri disiplini, yönetim, bilgisayar ve işletme bilimleri gibi üç farklı disiplini aynı kapta harmanlamayı başarmış, her üç disiplinin kesişim noktasında ilişkilendirdiği sektörler için kritik etkiye sahip bir disiplindir. Damar ve diğerleri (2018) Türkiye'de yazılımda kalite ile ilişkilendirilen çalıșma sayısının az olduğunu, bu alanda üniversitelerini meslek odalarının, sivil toplum kuruluşlarının daha üretken olmasının alanın gelişmesine çok önemli etki yaratabileceğini ifade etmişlerdir. YBS alanındaki araştırmacılar tarafından hızlı ve etkin bir şekilde alanın boşlukları doldurulabilir, küreselde gerçekleşen iyi uygulamalar Türkiye'de faaliyet gösteren firmalara uygulanması için daha fazla çalışma üretilebilir, küresel tartışmalarda daha fazla yer edinilebilir. 
Teknolojideki değişim ve gelişmelere paralel olarak, işletmelerin içinde bulunduğu ekosistem değişebilmektedir. Bu ekosistem içinde işletmeler, rekabet güçlerini bilgi teknolojilerine uyum, nitelikli işgücü, güvenilir ve kaliteli bilgiye sahip olarak artırabilirler (Kızıl vd., 2014:78-79). Dijital ikiz, endüstri 4.0 ve nesnelerin interneti, yapay zeka teknolojisinin gelişmesi ve $5 \mathrm{G}$ teknolojilerin yaygın şekilde kullanımı ve getirdiği dijital dönüşüm rüzgarı, kamu ve özel kurumlar için uyum sorununu, pek çok farklı yönden bir problem olarak karşımıza çıkarabilecektir. Kurumların yönetsel olarak sürdürülebilirliği, işletme disiplini içinde barındırdığı tüm işletme faaliyetlerine olası etkisi ve bu etkinin yarattığı uyum problemleri, sektörler içinde ortaya çıkacak rekabete ilişkin problemler, tüm bu ekosistem içinde bilgisayar bilimlerinin ve bununla ilişkili disiplinlerin günümüz işletme dünyasında rekabet için kritik bir araç olarak ortaya çıkması, alanda kendini yetiștirmiş YBS uzmanlarının önemini daha da artırmaktadır. Alanda kendini yetiștirmiş ve sadece ulusal değil uluslararası literatüre ve sahaya hakim, gelişmelerden haberdar akademisyenlerin sektör ihtiyaçlarına uygun, uluslararası kriterlere uyumlu işgücünün yetiştirilmesi için de çok değerli etki edeceği de ortadadır. Yönetim bilişim sistemlerinin ortaya çıkardı̆̆ insan kaynağının bu dönüşüme ayak uyduracak, yönetecek ve bu alana liderlik edebilecek düzeyde bilgi birikime sahip olması elzemdir.

Son yıllarda hızla açılan YBS lisans, yüksek lisans ve doktora programlarının ve buradan mezun olan öğrencilerin sayısında önemli bir artış söz konusudur (YÖK Akademik, 2021; YÖK İstatistik, 2021). Yukarıda çeşitli konu başlıkları altında da ifade edilen, araştırma kalitesinin niteliğinin artırılması ve alandaki akademisyen niteliğine etkisi algılanarak, gerek sektördeki gerekse akademideki mevcut ve gelecekteki insan kaynaklarının doğu planlanmasının önem görülebilmektedir.

Hatalı bir yazılım tercihinin kurumlara, marka kimliğine ve kişilere verebileceği zararlar; değişim maliyeti, çift sistem maliyeti, özelleștirme maliyetleri, yükseltme maliyeti, üçüncü taraf ürün maliyetleri, yazılım seçim maliyetleri, yeniden uygulama ve eğitim maliyetleri, bilinmeyen ihtiyaç maliyeti, zaman maliyetleri, firsat maliyetleri, müşteri algılama maliyeti gibi çeşitli maliyetler doğurduğu bildirilmiştir(Damar vd., 2018:328). Bu durum bilgisayar bilimlerinde çok işlenmeyen bir konuyu karşımıza getirmektedir. İstihdam edilen YBS mezunun doğru ürün ile kurumunu bulușturması kritik öneme sahiptir. Dijitalleşmenin kurumların her noktasına nüfus ettiği değerlendirildiğinde ve bilgi sistemlerinin tüm firma faaliyetlerinde kritik role sahip olmasl, karar ve karar destek süreçlerinde bilgi sistemlerinden beslenen yöneticinin faaliyetlerini doğru planlaması, günlük, kısa ve uzun vadeli planlarını, kurumsal stratejileri doğru yönetebilmesi için, doğru yazilımın tedariki önemlidir. Bunun kararının firmadaki ihtiyaç analizi sonrasında verilmesi YBS uzmanları tarafindan gerçekleștirilmektedir.

Bir başka önemli unsur da yazilım ürünü çok özellikli ve sıradan bir pazarlama ürününün olmamasıdır. Bunun nedeni her sistemin kendine özgü özellikleri içinde barındırması, yazilım süreçlerinde sistem analizi sonrasında sistemler tasarlanırken pek çok farklı araç ile ortak çalışma yapısına yazılım ürünlerinin sahip olmasıdır. Bu bağlamda YBS disiplini hem işletme hem de bilgisayar bilimleri alanında aldıkları eğitim ile bu alan için biçilmiş kaftan olarak görülebilir. Damar ve Özdağoğlu (2021), yazılımın ihracatı, yazılım firmalarının iç piyasada güçlendirilmesi konusunda Türkçe literatür hem araștırma alanı olarak, hem de saha içi faaliyet alanı olarak önemli bir potansiyele sahip olduğunu ifade etmiştir. Türkiye'deki YBS alanındaki dergilerde Türkiye adresli araştırmacıların odaklanmadığı bir konu olarak karşımıza çıkmıştır. Yukarıda da belirtildiği gibi, yazılım sektörü için en kritik paydaş yetişmiş insan kaynağıdır. Türkiye barındırdığı genç nüfusu ile bu alanda önemli bir dinamizme sahiptir. YBS disiplini ise bu potansiyelin daha iyi anlatılması, farkındalık 
oluşturulması, sektördeki kalite ve standartlaşma algısının gelişmesi, dünya gerçekliğine uygun insan kaynakları politikaları oluşturulması, ürünlerin dış piyasaya açılması ve bu yönde dünyada gelişen faaliyetler konusunda firmalar için farkındalık oluşturulması, pazarın gelişmesi ve rekabet edilebilirliğin geliştirilmesi için sektör raporları yayınlanması, alanın gelişmesinde en etkili olabilecek akademik disiplin olarak karşımızdadır.

\subsection{Türkiye'de YBS Alanının Gelişmesine Katkı Sunan Kişi, Kurum ve Etkinlikler}

Enformasyon sistemlerinin akademide eğitim programlarına dahil edilmesi altmışlı yıllarda işletme okullarında verilen ve programcılar ile işletmeciler arasında iletişimi sağlamayı amaçlayan tek bir ders ile başlamış ve daha önceleri sadece bilgisayarcl ve matematikçilerin alanı halinde olan alan esleği bilgisayarlar ile ilişkili olmayan kullanıcıları da ilgilendirmeye başlamıștır (Akpınar, 2011). 1970'li yıllarda bilgisayarların boyutunun ve yaygınlığının artmasına paralel olarak YBS alanı da gelişimini dünya genelinde arttırmaya başlamıştır (Weedmark, 2019). Bu gelişim ile birlikte eğitim alanında da YBS alanında çalışan araştırmacılar yetişmeye ve yeni eğitim programları açılmaya başlamıştır. Türkiye'de ilk YBS bölümü olarak kabul edilen lisans programı 1991 yılında Marmara Üniversitesi İşletme Fakültesi bünyesinde açlan İşletme Enformatiği bölümüdür (YBS Genel Bilgiler, 2021). Prof. Dr. Haludun Akpınar'ın İşletme Enformatiği bölümünün kurulması ve YBS alanın ülkemizde gelișmesine katkısı çok büyüktür (Akpınar, 2021). Yönetim Bilișim Sistemleri adı ile açllan ilk bölüm ise 1995 yılında Boğaziçi Üniversitesi'nde kurulmuştur (Boğaziçi Üniversitesi MIS, 2021). Günümüze geldiğimizde Türkiye'de 3'ü açık ve uzaktan öğretim, 62'si fakülte bünyesinde, 9'u yüksekokul bünyesinde olmak üzere toplam 74 adet üniversitede YBS bölümü bulunmaktadır (YÖK Atlas, 2021). Görüldüğü üzere 1991 yılında günümüze gelindiğinde yükseköğretimdeki lisans bölümü sayısı sektörün ihtiyaçları doğrultusunda ciddi bir artış göstermiştir.

2009 yılında bu bölümleri bir çatı altında toplamak adına işletme enformatiği ve yönetim bilişim sistemleri bölümlerini birleştiren YBSIE yapısı (www.ybsie.org) kurulmuştur (Vikipedi, 2021). Bu yapı altında bölüm başkanları bir araya gelerek ortak müfredat oluşturma ve ortak akademik faaliyetler yürütmek gibi birçok konu görülmüştür. Bu sürecin sonunda alınan kararlar doğrultusunda Türkiye'de YBS alanının en prestijli ve etkili etkinliği olan Uluslararası Yönetim Bilişim Sistemleri Konferansı'nın temelleri atılmış ve 2014 yılından itibaren her yıl düzenli olarak farklı üniversiteler tarafından yapılmış ve yapılmaya devam etmektedir (IMISC, 2021).

Bilgi Sistemleri Derneği'nin (AIS) Türkiye'ye hizmet veren şubesi (TRAIS) 2016 yllında kurulmuştur. $\mathrm{Bu}$ derneğin amacı Türkiye'de bilgi sistemleri ve teknolojisinin geliştirilmesi, yönetimi ve kullanımı ile uğraşan akademisyenler ve profesyoneller arasında fikir, deneyim ve bilgi alışverişini teşvik etmektir. TRAIS'in 2016 yılındaki kurucu üyeleri ve o dönemdeki görev yaptıkları kurumlar şu şekildedir: Doç. Dr. Mehmet Aydın (Kadir Has Üniversitesi), Prof. Dr. Nuri Başoğlu (İzmir Yüksek Teknoloji Enstitüsü), Prof. Dr. Izak Benbasat (British Columbia Üniversitesi), Hasan Çavuşoğlu (British Columbia Üniversitesi), Hüseyin Çavuşoğlu (Texas-Dallas Üniversitesi), Prof. Dr. Erman Coşkun (Sakarya Üniversitesi), Prof. Dr. Birgül Kutlu Bayraktar (Boğaziçi Üniversitesi), Doç. Dr. Bilgin Metin (Boğaziçi Üniversitesi), Prof. Meltem Özturan (Boğaziçi Üniversitesi) ve Prof. Dr. Aslı Sencer (Boğaziçi Üniversitesi) 'dir (TRAIS, 2021).

2021 yılı ekim ayı itibari ile YÖK Akademik üzerindeki Türkiye'de çalışan kadrolu öğretim üyeleri incelendiğinde temel alanı SosyalBeşeri ve İdari Bilimler ve bilim alanı olarak Yönetim Bilişim sistemleri seçilmiş 46 Profesör olduğu görülmektedir. Öğretim üyelerinin Profesör kadrosuna atanma tarihleri, görev yaptıkları üniversite, fakülte/yüksekokul/meslek yüksekokulu ve 
bölüm/program bilgileri Tablo 11'de görülmektedir.

Tablo 11: Bilim alanı YBS olan Profesör kadrosundaki öğretim üyeleri (YÖK Akademik, 2021)

\begin{tabular}{|c|c|c|c|c|}
\hline Ad Soyad & $\begin{array}{l}\text { Atanma } \\
\text { Yılı }\end{array}$ & Üniversite & Fakülte/Yüksekokul & Bölüm/Program \\
\hline Cengiz Yılmaz & 1992 & Konya Gıda ve Tarım Ün. & S.B.B.F & İktisadi ve İdari Programlar Programı \\
\hline Dursun Delen & 2012 & İbn Haldun Ün. & Yönetim Bilimleri Fakültesi & İșletme Bölümü \\
\hline Alaattin Parlakkılıç & 2021 & Ufuk Ün. & İ.̇̈.B.F & Yönetim Bilișim Sistemleri Bölümü \\
\hline Alper Ertürk & 2015 & İstanbul Ayvansaray Ün. & $\begin{array}{l}\text { İktisadi, İdari ve Sosyal Bilimler } \\
\text { Fakültesi }\end{array}$ & Yönetim Bilişim Sistemleri Bölümü \\
\hline Murat Paşa Uysal & 2019 & Bașkent Ün. & Ticari Bilimler Fakültesi & Yönetim Bilișim Sistemleri Bölümü \\
\hline Nihat Kasap & 2017 & Sabancı Ün. & Yönetim Bilimleri Fakültesi & Yönetim Bilimleri Bölümü \\
\hline Murat Komesli & 2020 & Yaşar Ün. & Uygulamalı Bilimler Yüksekokulu & Yönetim Bilișim Sistemleri Bölümü \\
\hline Sibkat Kaçtıoğlu & 1995 & İstanbul Ticaret Ün. & Mühendislik Fakültesi & Endüstri Mühendisliği Bölümü \\
\hline Gökhan Silahtaroğlu & 2015 & İstanbul Medipol Ün. & $\begin{array}{|lll|}\begin{array}{l}\text { İşletme } \\
\text { Fakültesi }\end{array} & \text { Yönetim } & \text { Bilimleri } \\
\end{array}$ & Yönetim Bilişim Sistemleri Bölümü \\
\hline Turan Erman Erkan & 2021 & Atılım Ün. & Mühendislik Fakültesi & Endüstri Mühendisliği Bölümü \\
\hline Ahmet Kaya & 2020 & Ege Ün. & Tire Kutsan Meslek Yüksekokulu & Bilgisayar Teknolojileri Bölümü \\
\hline Ŏguz Kaynar & 2019 & Sivas Cumhuriyet Ün. & İ.̇.B.F & Yönetim Bilișim Sistemleri Bölümü \\
\hline Mehmet Ali Alan & 2021 & Sivas Cumhuriyet Ün. & İ.İ.B.F & Yönetim Bilişim Sistemleri Bölümü \\
\hline Erman Coșkun & 2011 & İzmir Bakırçay Ün. & İ.̇.̇.B.F & Yönetim Bilișim Sistemleri Bölümü \\
\hline Halil Kemal İlter & 2021 & İzmir Bakırçay Ün. & İ.İ.B.F & Yönetim Bilişim Sistemleri Bölümü \\
\hline Abdulkadir Hızıroğlu & 2019 & İzmir Bakırçay Ün. & İ.İ.B.F & Yönetim Bilişim Sistemleri Bölümü \\
\hline Abdullah Naralan & 2018 & Recep Tayyip Erdoğan Ün. & İ.İ.B.F & İșletme Bölümü \\
\hline Ömür Akdemir & 2015 & Ankara Yıldırım Beyazıt Ün. & İșletme Fakültesi & Yönetim Bilișim Sistemleri Bölümü \\
\hline Süleyman Ersöz & 2018 & Kırıkkale Ün. & Mühendislik ve Mimarlık Fakültesi & Endüstri Mühendisliği Bölümü \\
\hline Müge Klein & 2021 & Türk-Alman Ün. & İ.̇̈.B.F & İșletme Bölümü \\
\hline $\begin{array}{ll}\text { Ela Sibel } & \text { Bayrak } \\
\text { Meydanoğlu } & \\
\end{array}$ & 2017 & Türk-Alman Ün. & İ.İ.B.F & İşletme Bölümü \\
\hline Uğur Yavuz & 2011 & Atatürk Ün. & İ.İ.B.F & Yönetim Bilișim Sistemleri Bölümü \\
\hline Üstün Özen & 2010 & Atatürk Ün. & İ.İ.B.F & Yönetim Bilișim Sistemleri Bölümü \\
\hline Yusuf Ziya Ayık & 2021 & Atatürk Üniversitesi & T.B.M. Yüksekokulu & Bilgisayar Teknolojileri Bölümü \\
\hline Vahap Tecim & 2011 & Dokuz Eylül Ün. & İ.İ.B.F & Yönetim Bilişim Sistemleri Bölümü \\
\hline Yllmaz Gökșen & 2012 & Dokuz Eylül Ün. & İ.̇̈.B.F & Yönetim Bilişim Sistemleri Bölümü \\
\hline Sevgi Özkan Yıldırım & 2017 & Orta Doğu Teknik Ün. & Enformatik Enstitüsü & Bilișim Sistemleri \\
\hline Tunçhan Cura & 2016 & İstanbul Ün. & İșletme Fakültesi & İşletme Bölümü \\
\hline Sevinç Gülseçen & 2012 & İstanbul Ün. & Rektörlük & Enformatik Bölümü \\
\hline İbrahim Halil Seyrek & 2017 & Kilis 7 Aralık Ün. & İ.İ.B.F & İșletme Bölümü \\
\hline Erdem Uçar & 2018 & Trakya Ün. & U.B.F & Yönetim Bilișim Sistemleri Bölümü \\
\hline Birgül Kutlu Bayraktar & 2010 & Boğaziçi Ün. & Uygulamalı Bilimler Yüksekokulu & Yönetim Bilișim Sistemleri Bölümü \\
\hline Sona Mardikyan & 2019 & Boğaziçi Ün. & Uygulamalı Bilimler Yüksekokulu & Yönetim Bilișim Sistemleri Bölümü \\
\hline Zuhal Tanrıkulu & 2014 & Boğaziçi Ün. & Uygulamalı Bilimler Yüksekokulu & Yönetim Bilișim Sistemleri Bölümü \\
\hline Bilgin Metin & 2021 & Boğaziçi Ün. & Uygulamalı Bilimler Yüksekokulu & Yönetim Bilişim Sistemleri Bölümü \\
\hline Ayșe Gül Toker & 2007 & Boğaziçi Ün. & İ.̇̈.B.F & İșletme Bölümü \\
\hline Meltem Seba Özturan & 2003 & Boğaziçi Ün. & U.B.Y. & Yönetim Bilişim Sistemleri Bölümü \\
\hline Ahmet Baran & 2018 & Erzincan Binali Yıldırım Ün. & Mühendislik-Mimarlık Fakültesi & Bilgisayar Mühendisliği Bölümü \\
\hline Aykut Hamit Turan & 2017 & Sakarya Ün. & İșletme Fakültesi & Yönetim Biliş̧im Sistemleri Bölümü \\
\hline Serkan Ada & 2019 & Karamanoğlu Mehmetbey Ün. & İ.İ.B.F & $\begin{array}{l}\text { Uluslararası Ticaret ve İşletmecilik } \\
\text { Bölümü }\end{array}$ \\
\hline Ahmet Nuri Başoğlu & 2009 & $\begin{array}{lll}\text { İzmir Yüksek } & \text { Teknoloji } \\
\text { Enstitüsü } & & \\
\end{array}$ & Mimarlık Fakültesi & Endüstriyel Tasarım Bölümü \\
\hline Haludun Akpınar & 1998 & Marmara Ün. & İşletme Fakültesi & Yönetim Bilişim Sistemleri Bölümü \\
\hline Türksel Bensghir & 2011 & $\begin{array}{|lrr|}\text { Ankara Hacl } & \text { Bayram } & \text { Veli } \\
\text { Üniversitesi }\end{array}$ & İ.İ.B.F & İșletme Bölümü \\
\hline Turgay Kalaycı & 2021 & Bandırma Onyedi Eylül Ün. & U.B.F & Yönetim Bilișim Sistemleri Bölümü \\
\hline Nursal Arıcı & 2021 & Gazi Ün. & U.B.F & Yönetim Bilișim Sistemleri Bölümü \\
\hline Alper Aytekin & 2021 & Bartın Ün. & İ.İ.B.F & Yönetim Bilișim Sistemleri Bölümü \\
\hline
\end{tabular}

Ün.: Üniversite, S.B.B.F. : Sosyal ve Beşeri Bilimler Fakültesi, İ.İ.B.F. : İktisadi ve İdari Bilimler Fakültesi, U.B.F: Uygulamalı Bilimler Fakültesi, U.B.Y. : Uygulamalı Bilimler Yüksekokulu

\section{SONUÇ ve ÖNERILER}

Türkiye'de YBS disiplini gelişmekte olan, her geçen gün yeni bir lisans, yüksek lisans ve doktora programının açıldığı bir disiplindir (YÖK Akademik, 2021; YÖK İstatistik, 2021).
Türkçe literatürde YBS dergileri üzerine bibliyometrik çalışmalar değerlendirildiğinde karşımıza çeşitli çalışmalar çıkmaktadır. Bunlardan birinci olarak değerlendirebileceğimiz Özköse (2017:1939)'nin çalışmasıdır. Çalışmasında, YBS 
alanındaki dergiler üzerine altı uzmanın değerlendirmesi ile 24 dergiye ulașmış ve bu dergiler üzerine yazar, ülke, kurum, içerik başlıkları ile bibiyometrik bir değerlendirme sunmuştur. Diğer bir çalışma da Kefkir (2019)'in çalışmasıdır. Çalışmada ikisi Avrupa'dan, ikisi Amerika Birleşik Devletleri'nden olmak üzere Yönetim Bilișim Sistemleri çalışma alanında yüksek niteliğe sahip toplam dört akademik derginin 20172018 yılları içinde yayınladığı makaleleri incelemiştir. Ergüner Özkoç (2019) ise çalışmasında, Türkiye'deki YBS çalışmalarınının bibliyometrik ve sosyal analizini incelemiştir.

Her üç çalışmadan farklı olarak gerçekleştirilen bu çalışma SCImago gibi uluslararası bir otorite tarafından Yönetim Bilişim Sistemleri dergileri olarak sınıflandırılmış bir dergi kümesi üzerinde genel üretkenlik değerlendirmesi yapmıştır. Türkiye'deki YBS disiplinini merkeze alarak, alandaki araştırmacıların akademik gelişimi, uluslararası literatüre hakim olması ve küresel literatürde trend konular üzerine genel bir değerlendirme sunmuştur. Hızla açılan YBS programlarındaki akademisyenlerin uluslararası literatüre katkıları konusunda bir değerlendirme ortaya koymaktadır. Ayrıca YBS alanının Türkiye'de gelişimine katkı sunan kişi, kurum veya fikirlere yer vererek bu alana bir gelecek vizyonu sunma gayretindedir. Elbette Tablo 11 üzerinde yer alan alanın öncü akademisyenlerinin yıllar içinde alana katkısından ve gerçekleştirdikleri proje ve etkinliklerden bir başlık altında toplamak yeterli görülmeyebilir. Türkiye'deki YBS disiplini daha kapsaml, tarihsel kronoloji ve önemli ve kritik olayların, mihenk taşlarının değerlendirildiği, anlatıldığı bir başka alan yazısının yazılması gelecek çalışmalar için önerilebilir.

Alanda Türk YBS diasporası olarak da ifade edebileceğimiz, eğitim hayatı veya akademik gelişiminin bir bölümü yurt dışında geçen araştırmacıların sadece ulusal literatüre değil uluslararası literatüre önemli katkılar sunmuş, alanın en önemli isimleri içinde yer almışlardır. $\mathrm{Bu}$ durum akademisyenlerin, yurt dışında gerek eğitim gerekse iş hayatının bir döneminde bulunmasının, ilgili akademik disiplinin gelişmesine önemli etkisi olduğunu göstermektedir.

$\mathrm{Bu}$ tür çalışmaların yapılmasının Türkiye'deki YBS alanındaki yayıncılık faaliyetlerinin uluslararası bilinirlik ve niteliğini artırma yönünde katalizör etki yaratacağı düşünülmektedir. Her ne kadar son yıllarda yönetim bilişim sistemleri alanında yoğun olarak yeni bölümler açllsa ve yoğun bir akademisyen istihdamı yapılsa da Türkiye'de yürütülen yayıncılık faaliyetleri yeterli görülmemektedir. Scopus indeksinde yer alan YBS alanında Türkiye adresli yayıncılık faaliyeti yürüten dergi sayısı birdir (Sobiad, 2021). DergiPark üzerinde TR dizinde taranan dergi sayısı sadece altı, diğer indekslerce taranan dergi sayısı ise 28'dir (Dergipark, 2021).

Dergilerin uluslararası dizinlerde taranması için ilgili dergi yöneticilerinin inisiyatif alması ve bu doğrultuda çalışması gerekmektedir. $\mathrm{Bu}$ sürecin uzun soluklu bir süreç olduğu unutulmamalı ve sonuçtan çok kalitenin arttırılmasına odaklanılmalıdır. Bilimsel indeks editörleri, taranmak için başvuruda bulunan dergilerin kurallarının yapısına, görev paylaşımına, makalelerin kalitesine, atıf miktarına, mizanpaj düzeninden, etik ve akademik ilkelere riayet edilmesi gibi geniş bir kapsamda değerlendirme yapmaktadır. Farklı dillerde yayın kabul edilen dergilerde dil editörünün bulunması, çok farklı alanlarda yayın kabul edilenlerde bu alanların uzmanı olana alan editörlerinin aktif görev alması ve hakemlik süreçlerinin sağlıklı yürütülmesine kadar birçok konu dikkate alınmaktadır. Ayrıca, uluslararası üst düzey indekslerde yer almak için istisnalar bulunmasına rağmen (Uluslararası İlişkiler Dergisi, Bilig, Gazi Üniversitesi Mühendislik Mimarlık Fakültesi Dergisi, Teknik Dergi, BELLETEN, Milli Folklor, OLBA, vb.) uluslararası geçerliliği olan bir dilde yayın yapıyor olmak büyük önem taşımaktadır. Tümüyle bu dilde yayın yapılmasa bile özellikle 
atıf sayısını arttırabilmek adına makalelerin içinde yabancı dilde genişletilmiş bir özet bulunması katkı sağlayabilmektedir.

Dergilerin uzun yıllar düzenli olarak yayın yapması, isimlerinin değişmeden yayına devam etmesi gibi kurallara uyulması fayda sağlamaktadır. Ayrıca dergide yayınlanacak çalışmaların uluslararası nitelikte bilime katkı sunacak kalitede yayınlar olması derginin ilgili indekslere kabulünde büyük rol oynamaktadır. Dergide yayınlanan makalelerin aldığı atıflar kullanılarak elde edilen etki faktörü (Impact Factor) de önemlidir. Atıfların niceliği ile birlikte niteliği de ön plana çıkmaktadır. Uluslararası mecralarda kendini kanıtlamış bilim insanlarından ve dergilerde yayınlanan makalelerden yapılan atıflar derginizin saygınlığını ve bilinirliğini arttıracaktır. Kaliteli makalelerin dergide yayınlanması bunu sağlayabilirken tek başına yeterli olmayabilmektedir. Derginin ve dergide yayınlanan makalelerin görünürlüğü ve ulaşılabilirliğinin de mümkün olan en iyi seviyeye getirilmesi gerekmektedir. $\mathrm{Bu}$ noktada açık ve ücretsiz erişimin önemi ön plana çıkmaktadır. İlgili derginin açık erişim olması araştırmacı ve akademisyenlerin ücretsiz bir șekilde makalelere ulașıp okumalarına imkan tanımaktadır. Ek olarak makalelerin farklı indekslerde paylaşılması, yazarların da Linkedin, Researchgate, Academia, Arxiv ve üniversitelerin açık erişim siteleri vb. platformlarda çalışmalarını paylaşmaları görünürlük ve ulaşılabilirliği etkilemektedir.

Uluslararası indekslerde yer alma vizyonu ile yapılabilecekler listesi genişletilebilir. Aslında her geçen gün alanda açlan yeni program veya bölümler, yüksek lisans ve doktora programları değerlendirildiğinde, YBS alanında Türkiye'nin elinde ciddi bir potansiyel olduğu ortadadır. $\mathrm{Bu}$ potansiyelin uluslararası literatüre katkı sunan araştırmacılar tarafından yönlendirilmesi, alanın Türkiye'deki niteliğini artıracaktır. Bu yönüyle konu değerlendirildiğinde ESCI, Scopus veya SSCI indekslerince taranan dergi sayısının nasıl artırılacağı üzerine yukarıdaki önerilerin bağlamı genişletilerek Yönetim Bilişim Sistemleri Kongresi (IMISC) gibi Türkiye'nin en önemli YBS kongresinde tartışılabilir. Alanın öncü hocaları tarafından dernek benzeri bir yapı ile MIS Quarterly benzeri (Kurulan bir dernek tarafindan kongre ve dergi yayıncılıkları koordine edilmektedir.) örneğinde olduğu gibi bir kurumsal yapı ile alanın uluslararasılaşması için stratejik bir adım atılabilir.

Yönetim Bilişim Sistemleri alanındaki 104 derginin ilişkilendirildiği en yoğun alanlar ile SCOPUS tarafindan taranan ve kendisini Yönetim Bilişim Sistemleri alanıyla ilişkilendirmiş Q1 dergiler incelendiğinde sosyal bilimler, mühendislik ve sağlık gibi birçok alanda ilişkiler görülmektedir. $\mathrm{Bu}$ durum bilgisayar bilimleri ve teknolojinin ana eksenlerinden birini olușturan bir alan için normal gibi görünebilir lakin yapılan incelemelerde Türkiye özelinde bilgisayar bilimleri disiplininde yeterli katkının oluşmadığı görülmektedir. $\mathrm{Bu}$ durumun oluşmasında yapılan çalıșmaların kapsamı ve metotları ile birlikte YBS alanındaki araştırmacı ve akademisyen insan kaynağının niteliği de etkili olmaktadır. İlgili insan kaynağı YÖK Akademik üzerinden incelendiğinde (YÖK Akademik, 2021) çok farklı disiplinlerde eğitim almış araştırmacıların bu alanda görev yaptı̆̆ ve akademik çalışmalar ortaya çıkardığı görülebilmektedir. $\mathrm{Bu}$ bir zenginlik olarak görülebilecekken alanın ruhuna aykırı kişilerin istihdamı hem yetişen yeni araştırmacıların kalitesini, hem uluslararası saygınlı̆̆ hem de uluslararası yayın sayısı ve kalitesini etkilemektedir.

$\mathrm{Bu}$ tür çalışmaların Türkiye'deki YBS disiplininin uluslararası görünürlüğü konusunda önemli bir durum değerlendirmesi gerçekleștirmektedir. Türkiye'de son ylllarda hızla açılan lisans, yüksek lisans ve doktora programları ile YBS disiplininin yıllar içinde uluslararası Q1 dergilerdeki bilimsel üretkenliği ve uluslararası katkısı yereldeki gelişmeler ile uyum içinde gelişmediği ortaya konulan bulgular çerçevesinde görülmektedir. 
YBS disiplini pek çok farklı disiplinden araştırmacının bilgi birikimini aynı potada erittiği ve sağlık sektöründen, savunma sanayisine, bilgiye, bilgi yönetimine ve kararın gereksinim duyulduğu her noktada ihtiyaç duyulan kritik bir disiplindir. İlgili alan için uluslararası literatürden beslenmenin kritik önemde olması yanında uluslararası literatüre katkı sunmak ve Türkiye'den araștırmacıların alana yön vermesi de kritik önemde görülmektedir.

Türkiye'deki YBS alanı ne ABD'deki olduğu kadar yaşlı ve oturmuş, ne de Danimarka veya Finlandiya'daki gibi dinamik bir durumdadır. Hızla açılan yeni YBS bölümlerinin ülke ekonomisine katkı sunacak, genç ve dinamik, dünyada kolaylıkla dolaşabilecek bir iş gücü niteliğinde mezun olmalarının sağlanması gerekmektedir.

Türkiye adresli araştırmacıların bu yönde her yıl gerçekleştirdikleri kongreleri uluslararası boyuta taşımaları yanında, uluslararası işbirlikleri geliștirebilecekleri bir yapıya girmeleri şiddetle önerilmektedir. Bunun için yapılabilecekler;

- Araștırmacı ve akademisyenlerin uluslararası geçerli dillerde yayın yapmasını sağlayacak şekilde planlanması veya bu eğitimler için yurtiçi veya yurtdışında bulunmak için destek verilmeli,

- Özellikle yüksek lisans ve doktora düzeyinde uluslararası öğrenci kabulüne önem verilmeli,

- Scopus, ESCI, SCI ve SSCI gibi indekslerce taranan uluslararası nitelikte YBS dergilerinin kurulmasının sağlanması ve sayılarının artırılması,

- Türkiye'de yeni açılan YBS programlarında akademisyen olarak görev alabilmek için yurtdışı deneyim veya tecrübeyi en az bir yıl zorunlu kılınması,

- Alanında yetkin araştırmacıların yurtdışındaki araştırma merkezleri veya üniversitelerde Türkiye'deki ilgili disiplinlerin potansiyel uluslararasılaşmaya etkisi dikkate alınarak istihdam edilmesinin kolaylaştırılması,

- Doktora sonrası, dünya genelinde ön plana çıkmış kurumlarda akademisyenlerin misafir öğretim üyesi olarak bulunması veya özellikle Q1 dergilerde bilimsel üretkenlik konusunda ön plana çıkan araştırmacılar ile ortak çalışma yürütmeyi bir şekilde başarmaları,

- $\quad$ Proje odaklı çalıșmalara yer verilmesi ve bu projelerde farklı disiplin veya ülkelerden araștırmacıların görev almasının sağlanması,

şeklinde sayılabilir.

Çalışmada bazı grafik ve tablolarda makale yazım dili Türkçe olmasına rağmen İngilizce içerikler kullanılmıştır. Bunun nedeni bibliyometrik veritabanlarında tercih edilen veri setindeki doküman türlerinin İngilizce olması ve bibliyometrik veri tabanlarının genel olarak İngilizce veri setiyle daha kolay kullanıma sahip olmasıdır. Bununla birlikte bazı terimlerin İngilizce'den Türkçe'ye dönüştürmenin okuyucu için anlam kargaşasına yol açabileceği düşüncesi de bir başka nedendir. Çalışma ile ilgili olarak özellikle ulusal düzeyde yayın yapan veya Scopus dişındaki uluslararası indekslerde taranan dergilerde dahil edilerek çalışma genişletilebilir. Türkçe yapılan yayınların incelemeye dahil edilmesi ile literatür konusunda daha kapsaml bir bilgi sahibi olunabilir. 


\section{KAYNAKÇA}

Abedin, B., Jafarzadeh, H., \& Olszak, C. M. (2021). Thirty six years of information systems management: A bibliometric and thematic analysis. Information Systems Management, 38(2), 151-164.

Adeoti-Adekeye, W. B. (1997). The importance of management information systems. Library Review, 46 (5), 318-327.

Akpınar, H. (2021). Prof. Dr. Haludun Akpınar Kişisel Web Sitesi. Erişim Tarihi: 03/11/2021, http://haldunakpinar.com/cv.htm

Akpınar, H. (2011). Türkiye'de Enformasyon Sistemleri Öğretiminde 20. Yll. Uluslararası 9. Bilgi, Ekonomi ve Yönetim Kongresi Bildirileri, 01 Ocak 2011, ss.565-665.

Al-Mamary, Y. H., Shamsuddin, A., \& Abdul Hamid, N. A. (2013). The impact of management information systems adoption in managerial decision making: A review. Management Information Systems, 8(4), 010017.

Argyris, C. (1971). Management information systems: The challenge to rationality and emotionality. Management science, 17(6), B275.

Baskerville, R. L., \& Myers, M. (2002). Information systems as a reference discipline. MIS Quarterly, 26(1),1-14.

Bastl, E., Kuzey, C., \& Delen, D. (2015). Analyzing initial public offerings' short-term performance using decision trees and SVMs. Decision Support Systems, 73, 15-27.

Benbasat I. ve Zmud R.W., (2003). The Identity Crisis within the Is Discipline: Defining and Communicating the Discipline's Core Properties, MIS Quarterly,27(2), 183-194.

Benbasat, I. (2021). Izak Benbasat. Erişim Tarihi: 05.10.2021. https://en.wikipedia.org/wiki/Izak_Benbasat

Benbasat, I., Goldstein, D. K., \& Mead, M. (1987). The case research strategy in studies of information systems. MIS Quarterly, 11(3), 369-386.
Bensghir Kaya, T. (2002). Türkiye'de Yönetim Bilișim Sistemleri Disiplininin Gelişimi Üzerine Düşünceler. Amme İdaresi Dergisi, 35(1), 77 103.

Beydoun, G., Abedin, B., Merigó, J. M., \& Vera, M. (2019). Twenty years of information systems frontiers. Information Systems Frontiers, 21(2), 485-494.

BlogScopus, (2021). Scopus Blog. Erişim Tarihi: 15/08/2021, https://blog.scopus.com/about

Boğaziçi Üniversitesi MIS, (2021). Boğaziçi Üniversitesi Yönetim Bilişim Sistemleri Bölümü Web Sitesi. Erişim Tarihi: 03/11/2021,

http://www.mis.boun.edu.tr/hakkimizda

Cheon, M. J., Lee, C., \& Grover, V. (1992). Research in MIS-Points of work and reference: A replication and extension of the Culnan and Swanson study. ACM SIGMIS Database: the DATABASE for Advances in Information Systems, 23(2), 21-29.

Cocosila, M., Serenko, A., \& Turel, O. (2011). Exploring the management information systems discipline: a scientometric study of ICIS, PACIS and ASAC. Scientometrics, 87(1), 116.

Culnan, M. J. (1986). The intellectual development of management information systems, 1972-1982: A co-citation analysis. Management science, 32(2), 156-172.

Culnan, M. J. (1987). Mapping the intellectual structure of MIS, 1980-1985: A co-citation analysis. MIS Quarterly, 11(3), 341-353.

Culnan, M. J., \& Swanson, E. B. (1986). Research in management information systems, 19801984: Points of work and reference. MIS Quarterly, 10(3), 289-302.

Damar, M., \& Özdağoğlu, G. (2021). Yazılım Sektörü ve Uluslararasılaşma, Politika Önerileri. Editör, Ömer Aydın \& Çağdaş Cengiz. Teknoloji ve Uluslararası İlişkiler. Nobel Yayıncılık: Ankara. 
Damar, M., Dereli, Y., \& Dicle, Z. (2015). deuKariyeriM: Üniversiteler İçin Bir Kariyer Yönetim Sistemi. Bilișim Teknolojileri Dergisi, 8(2), 89-98.

Damar, M., Özdağoğlu, G., \& Özdağoğlu, A. (2018). Software Quality and Standards on a Global Scale: Trends in the Literature from Scientific and Sectoral Perspective. Alphanumeric Journal, 6(2), 325-348.

Damar, M., Özdağoğlu, G., \& Özveri, O. (2020). Bilimsel üretkenlik bağlamında dünya sıralama sistemleri ve Türkiye'deki üniversitelerin mevcut durumu. Üniversite Araştırmaları Dergisi, 3(3), 107-123.

Damar, M., Özdağoğlu, G., \& Özveri, O. (2021). Türkiye'de Yükseköğretim Kurumlarının Bilimsel Üretkenliğinin İzlenmesi: Mevcut Durum Analizi Ve Öneriler. Yükseköğretim Ve Bilim Dergisi, 11(1), 35-48.

de Carvalho Pereira, F., Verocai, H. D., Cordeiro, V. R., Gomes, C. F. S., \& Costa, H. G. (2015). Bibliometric analysis of information systems related to innovation. Procedia Computer Science, 55, 298-307.

DergiPark, (2021). Dergi Park Akademik Yayıncılık. Erişim Tarihi: 05/10/2021, https://dergipark.org.tr/tr/

Donthu, N., Badhotiya, G. K., Kumar, S., Soni, G., \& Pandey, N. (2021). A retrospective overview of Journal of Enterprise Information Management using bibliometric analysis. Journal of Enterprise Information Management, DOI:10.1108/JEIM-09-20200375

Elsevier, (2021). About Elsevier. Erişim Tarihi: 15/08/2021, https://www.elsevier.com/about

Ergüner Özkoç, E. (2019). Türkiye'de Yönetim Bilişim Sistemleri Çalışmalarının Bibliyometrik Yapısı ve Sosyal A $\breve{g}$ Analizi ile Çözümlenmesi. Sosyal Bilimler Dergisi, 12(1): 25-43.

Farhoomand, A. F. (1987). Scientific progress of management information systems. ACM
SIGMIS Database: the DATABASE for Advances in Information Systems, 18(4), 48-56.

Gillenson, M. L., \& Stutz, J. D. (1991). Academic issues in MIS: Journals and books. MIS Quarterly, 447-452.

Heeks, R., \& Nicholson, B. (2002). Software export success factors and strategies in developing and transitional economies. Development Informatics Working Paper, (12),1-22.

Holsapple, C. W. (2008). The pulse of multiparticipant systems. Journal of Organizational Computing and Electronic Commerce, 18(4), 333-343.

IMISC, (2021). Uluslararası Yönetim Bilişim Sistemleri Konferansı. Erişim Tarihi: 03/11/2021, https://2021.imisc.net/

Islam, M. A., \& Widen, G. (2021). Bibliometric analysis of the VINE Journal of Information and Knowledge Management Systems: 2000-2020. VINE Journal of Information and Knowledge Management Systems, 2059-5891.

Karaman, D., Damar, M., \& Özdağoğlu, G. (2021). Web of Science Penceresinden Türkiye Adresli Hukuk Yayınlarına Genel Bakış. Üniversite Araştırmaları Dergisi, 4(2), 193208.

Katerattanakul, P., Han, B., \& Rea, A. (2006). Is information systems a reference discipline? Communications of the ACM, 49(5), 114-118.

Kefkir, A.T. (2019). Yönetim Bilişim Sistemleri Disiplininin Bibliyometrik Analizi. Başkent Üniversitesi Sosyal Bilimler Enstitüsü Yönetim Bilişim Sistemleri Anabilim Dalı Yönetim Bilişim Sistemleri Yüksek Lisans Programı, Ankara.

Kızıl C., Şeker S.E., \& Bozan D. (2014). Bilgi Teknolojileri ve Bilgisayar Kullanımının Öğrencilerin Muhasebe Dersindeki Başarısına Etkisi. Alphanumeric Journal, 2(2):77-97.

Kokol, P., Saranto, K., \& Vošner, H. B. (2018). eHealth and health informatics competences: A systemic analysis of literature production 
based on bibliometrics. Kybernetes, 47(5), 1018-1030.

La Paz, A., Merigó, J. M., Powell, P., Ramaprasad, A., \& Syn, T. (2020). Twenty-five years of the Information Systems Journal: A bibliometric and ontological overview. Information Systems Journal, 30(3), 431-457.

Laudon, K., \& Laudon, J. (2002). Management Information Systems - 7th ed, New Jersey, USA: Prentice-Hall,.

Merigó, J. M., Pedrycz, W., Weber, R., \& de la Sotta, C. (2018). Fifty years of Information Sciences: A bibliometric overview. Information Sciences, 432, 245-268.

Moore, G. C., \& Benbasat, I. (1991). Development of an instrument to measure the perceptions of adopting an information technology innovation. Information systems research, 2(3), 192-222.

Nath, R. P., \& Badgujar, M. (2013). Use of Management Information System in an Organization for Decision Making. ASM's International E-Journal of Ongoing Research in Management And IT, 2 (6), 160-171.

Osterweil L., Clarke L.A., DeMillo R.A., Feldman S.I., McKeeman B., Miller E.F., Salasi J. (1996). Strategic Directions in Software Quality. ACM Computing Surveys, 28(4):738-750.

Oztekin, A., Delen, D., Turkyilmaz, A., \& Zaim, S. (2013). A machine learning-based usability evaluation method for eLearning systems. Decision Support Systems, 56, 63-73.

Özdağoğlu, G., Damar, M., Özdağoğlu, A., Damar, H. T., \& Bilik, Ö. (2020). 80’lerden Günümüze Yükseköğretimde Kalite Çalışmaları: Küresel Ölçekte Bilimetrik Bakış. Kastamonu Eğitim Dergisi, 28(1), 482-493.

Özköse, H. (2017). Yönetim Bilişim Sistemleri Alanının Türkiye ve Dünya'daki Bibliyometrik Analizi ve Haritası. Yayınlanmamış Doktora Tezi. Gazi Üniversitesi Bilişim Enstitüsü, Yönetim Bilişim Sistemleri Anabilim Dalı, Ankara.
Patterson, A. (2005). Information Systems Using Information. Learning and Teaching Scotland.

Reddy, G. S., Srinivasu, R., Rikkula, S. R., \& Rao, V. S. (2009). Management information system to help managers for providing decision making in an organization. International Journal of Reviews in Computing, 5(1), 1-6.

SCImago, (2021). SJR - SCImago Journal \& Country Rank [Portal]. Retrieved Date you Retrieve, from http://www.scimagojr.com

Scimagojr, (2021). MIS Quarterly: Management Information Systems. Erişim Tarihi: 2/06/2021. https://www.scimagojr.com/journalsearch.p $\mathrm{hp} ? \mathrm{q}=12402 \&$ tip $=$ sid $\&$ clean $=0$

Scopus, (2021). Scopus. Erişim Tarihi: 15/08/2021,

https://www.elsevier.com/_data/assets/pdf _file/0017/114533/Scopus_GlobalResearch_F actsheet2019_FINAL_WEB.pdf

Sobiad, (2021). International Journal of eBusiness and eGovernment Studies (IJEBEG). Social Sciences Bibliography Indexes and Archives Data. Erişim Tarihi: 09/10/2021 https://sobiad.org/eJOURNALS/journal_IJEB EG/index.html/

TRAIS, (2021). The Turkey Chapter of the Association for Information Systems. Erişim Tarihi: 03/11/2021, http://www.traisnet.org

Weedmark, D. (2019). The History of Management Information Systems. bizfluent. Erişim Tarihi: 03/11/2021, https://bizfluent.com/about-5444925history-management-informationsystems.html

Vikipedi, (2021). Yönetim Bilişim Sistemleri. Erişim Tarihi: 03/11/2021, https://tr.wikipedia.org/wiki/Y\%C3\%B6neti m_Bili\%C5\%9Fim_Sistemleri\#E\%C4\%9Fitim

YBS Genel Bilgiler, (2021). Marmara Üniversitesi İşletme Fakültesi Yönetim Bilişim Sistemleri Bölümü Web Sitesi. Erişim Tarihi: 03/11/2021, 
http://mis.isletme.marmara.edu.tr/genelbilgiler

Yılmaz, M. (2006). Lotka yasası ve Türkiye'de kütüphane ve bilgi bilimi literatürü. Türk Kütüphaneciliği, 16(1), 61-69.

YÖK Akademik, (2021). Akademik Arama Yükseköğretim Kurulu. Erişim Tarihi: 05/10/2021,
https://akademik.yok.gov.tr/AkademikArama /

YÖK Atlas, (2021). Yükseköğretim Program Atlası. Erişim Tarihi: 03/11/2021, https://yokatlas.yok.gov.tr/lisansanasayfa.php

YÖK İstatistik, (2021). Yükseköğretim Bilgi Yönetim Sistemi. Erişim Tarihi: 05/10/2021, https://istatistik.yok.gov.tr/ 